\title{
PENGARUH KONFLIK INTERPERSONAL, WORK-FAMILY CONFLICT \\ DAN STRES, TERHADAP KEPUASAN KERJA DAN DAMPAKNYA TERHADAP KEPUASAN HIDUP
}

\author{
Adnan Rajak \\ Fakultas Ekonomi Universitas Khairun Ternate \\ e-mail:adnanrajak@yahoo.co.id
}

\begin{abstract}
This research aims to analyze that the effect of interpersonal conflict, work family on work stress and job satisfacton, effect of work stress on job satisfactin, dan effect of job satisfaction on life satisfaction at Civil Servant Secretariat of Ministry of Eduacation and Cultural. Research Method that used is survey method at fixed lecturer of Secretariat of Ministry. This Research Type is the verification descriptive. Sample size research this is the 200 Civil Servant and the technique used strafied random sampling. Method that used to test of hypothesis is Structural Equation Modeling (SEM). The result of the study, (1) Conflict of interpersonal positive effect on the work stress, (2) Work-family conflict negative effect on the Work stress, (3) Conflict of interpersonal negative effect on the Job satisfaction, (4) Work-family conflict negative effect on the Job satisfaction, (5) Work Stress negative effect on the Job satisfaction, and (6) Job satisfaction positive effect on the Life satisfaction. Recommendation of this study is the Secretariat of Ministry should manage interpersonal conflict and family conflict in a way to identify and evaluate accurately through approaches, Collaborating, problem solving, Avoiding, Competing and Accommodating. While the employee stress can be done through the Individual and organizational approach.
\end{abstract}

Keywords: Interpersonal Conflict, Work Family Conflict, Work Stress, Job Satisfaction, and Life Satisfaction

\begin{abstract}
Abstrak
Tujuan dalam penelitian ini adalah untuk mengetahui pengaruh konflik interpersonal, work-family conflict, terhadap stres kerja dan kepuasan kerja, serta pengaruh stres kerja terhadap kepuasan kerja dan kepuasan kerja terhada Kepuasan Hidup PNS pada Sekretariat Jenderal Kementerian Pendidikan dan Kebudayaan. Metode penelitian yang digunakan adalah metode survey pada PNS Sekretariat Jenderal. Ukuran sampel penelitian ini adalah 200 PNS dan menggunakan teknik strafied random sampling. Meode yang digunakan untuk menguji hipotesis adalah analisis Persamaan Model Struktural. Hasil penelitian ditemukan bahwa, (1) Konflik interpersonal berpengaruh positif terhadap Stres kerja; (2) Work-family conflict berpengaruh positif terhadap Stres kerja; (3) Konflik interpersonal berpengaruh negatif terhadap Kepuasan kerja; (4) Work-family conflict berpengaruh negatif terhadap Kepuasan kerja; (5) Stres kerja berpengaruh negatif terhadap kepuasan kerja; dan (6) Kepuasan kerja berpengaruh positif terhadap kepuasan hidup. Rekomendasi penelitian ini adalah Sekretariat Jenderal sebaiknya mengelola konflik interpersonal dan konflik keluarga dengan cara melakukan identifikasi secara akurat dan mengevaluasinya melalui pendekatan-pendekatan Collaborating, problem solving, Avoiding, Competing, dan Accomodating. Sedangkan stres kerja pegawai dapat dilakukan melalui Pendekatan Individual, dan Pendekatan organisasi.
\end{abstract}

Kata kunci: Konflik Antar Pribadi, Work-Family Conflict, Stres Kerja, Kepuasan Kerja, dan Kepuasan Hidup 


\section{PENDAHULUAN}

Tujuan Pendidikan Nasional sebagaimana tertuang dalam Undang-Undang Sisdiknas Tahun 2003 dapat tercapai, apabila ditunjang oleh sumber daya manusia yang berkualitas pada umumnya di lingkungan Kementerian Pendidikan dan Kebudayaan dan khususnya sumber daya manusia di lingkungan Sekretariat Jenderal Kemdikbud. Peningkatan kualitas sumber daya manusia harus menjadi prioritas utama untuk mendorong keberhasilan pembangunan manusia seutuhnya. Tanpa sumber daya manusia yang berkualitas, maka di masa depan bangsa Indonesia akan tertinggal dan kalah dalam berkompetisi dengan negaranegara lain.

Di setiap Biro pada Sekretariat Jenderal

Kemdikbud memiliki tingkat formalitas dan kompleksitas yang sangat tinggi. Hal tersebut disebabkan karena, setiap biro diharuskan bekerja sesuai dengan standar yang telah ditentukan dalam Undang-Undang (UU), Peraturan Pemerintah (PP), Keputusan Menteri (Kepmen), dan Instruksi-instruksi Menteri Pendidikan dan Kebudayaan lainnya. Dalam hubungan kerja antar sesama pegawai baik didalam unit kerja maupun diluar unit kerja berpotensi menimbulkan konflik. Karena itu, pimpinan (Kepala Biro, Kepala Bagian dan Sub Bagian) harus mampu mengelola konflikkonflik yang muncul yakni konflik yang bersumber di dalam unitnya maupun konflik yang bersumber dari luar unitnya (biro lain dan keluarga). Salah satu alasan mengapa konflik harus dikelola adalah karena konflik pasti muncul di setiap sisi kehidupan manusia baik ditempat kerja dan diluar tempat kerja.

Konsekuensi dari konflik terhadap seseorang mungkin bervariasi di antaranya adalah menciptakan kecemasan, ketegangan, frustasi, atau rasa bermusuhan (Robbins dan Judge, 2008). Dampak konflik dalam organisasi dapat juga diakibatkan oleh tujuan, nilai (value), atau opini seorang individu akan atau sedang dihalangi oleh individu atau kelompok lain (Dreu, 2007). Dengan demikian, seorang individu yang tidak mau menerima ide-ide atau gagasan dari individu lainnya, ketika melaksanakan tugas (task) dan hubungan (relationship) dengan individu lain akan menimbulkan konflik yang dapat mengakibatkan seorang pegawai mengalami stres kerja.
Konflik interpersonal (antarpergawai) dalam organisasi dapat mempengaruhi tingkat stres, apabila konflik tersebut belum diselesaikan dan terus berlangsung pada saat seorang individu berinteraksi dengan tugasnya dan individu lainnya. Selain faktor konflik antar pribadi (interpersonal conflict) mempengaruhi stres kerja seorang individu, work family conflict (konflik akibat dari intervensi pekerjaan di dalam keluarga) juga berpengaruh terhadap stres kerja individu ditempat kerja. Sifat alami dari work-family conflict adalah penting karena konsekuensi dari konflik adalah bergantung pada dimana konflik berasal serta gangguan antara kedua domain (pekerjaan dan keluarga) secara alami saling mempengaruhi antara keduanya.

Hasil penelitian Mckee (2007) menjelaskan bahwa intervensi pekerjaan dalam keluarga seperti, overload dan kerja lembur (overtime) dapat menyebabkan menurunnya kesehatan psikis dan fisik sehingga berdampak pada konflik keluarga dan dapat terjadi sebaliknya. Hasil penelitian tersebut didukung oleh hasil penelitian Grzywacz, et al. (2008) yang menunjukan bahwa, kelelahan psikis (psychological) dan fisik (physical) berpengaruh postif terhadap konflik keluarga akibat dari intervensi pekerjaan (work-family conflict).

Para pegawai Sekretariat Jenderal Kementerian Pendidikan dan Kebudayaan mengalami konflik ketika melaksanakan tugas dan fungsinya masing-masing, baik dalam setiap biro, bagian-bagian, dan sub-sub bagian. Dengan kata lain bahwa di dalam melaksanakan tugas dan fungsinya, setiap bagian dan sub bagian pada masing-masing biro secara kontinyu saling berkoordinasi dalam setiap pekerjaan memiliki potensi konflik. Konflik akan terjadi ketika pegawai pada sub-bagian dan bagian-bagian pada biro umum memiliki ketidakcocokan kepentingan, tujuan, dan nilai. Hal tersebut juga dapat disebabkan oleh keterbatasan sumberdaya, perbedaan tujuan, kekeliruan dalam komunikasi, dan perbedaan kepribadian (Janazs, et al. 2006).

Berbagai konflik yang terjadi didalam organisasi dapat berakibat terhadap tingkat stres kerja seorang karyawan yang pada akhirnya berdampak terhadap tingkat kepuasan kerja seseorang. Sejalan dengan hal tersebut, hasil penelitian Zhao dan Yamaguchi (2008) menjelaskan bahwa tekanan organisasional dan 
hubungan antar pribadi berhubungan negatif dengan kepuasan kerja. Dengan demikian, pihak manajemen bertanggungjawab terhadap konflik-konflik yang terjadi di dalam organisasi. Dengan kata lain, konflik yang terjadi harus dikelola dengan baik, bukan menghindari atau mengabaikannya.

Pegawai sangat menginginkan pekerjaan atau tugas-tugasnya memberikan manfaat terhadap dirinya. Jika sebuah pekerjaan memberikan manfaat terhadap dirinya, maka akan menimbulkan perasan-perasaan positif (kepuasan kerja) terhadap pekerjaannya. Sejalan dengan hal tersebut dikemukakan oleh Mathis dan Jackson (2006) bahwa kepuasan kerja adalah keadaan emosional yang positif yang merupakan hasil dari evaluasi pekerjaan seseorang.

Menurut Akehurst, et al. (2009) bahwa seseorang dengan kepuasan kerja tinggi akan menyukai pekerjaannya secara umum, dimana seseorang merasakan diperlakukan selayaknya dan percaya bahwa pekerjaan mempunyai banyak segi yang diinginkan. Hal tersebut menunjukan bahwa pekerjaan merupakan faktor yang sangat penting dalam menentukan kepuasan kerja seseorang. Lebih lanjut dikatakan bahwa kepuasan kerja adalah kumpulan perasaan dan kepercayaan (anggapan) yang dimiliki setiap individu tentang pekerjaannya saat ini. Survei telah menetapkan terdapat $80 \%$ 90\% orang adalah secara relatif terpuaskan dengan pekerjaan mereka (Ghazzawi, 2008). Dengan demikian, Kepuasan kerja seseorang tergantung pada selisih antara harapan, kebutuhan atau nilai dengan apa yang menurut pandangan atau persepsinya yang telah dicapai melalui pekerjaannya. Jadi, seorang akan merasakan kepuasan jika tidak ada perbedaan antara apa yang diinginkan dengan apa yang sesungguhnya terjadi, sebaliknya, seseorang merasakan ketidakpuasan kerja, apabila terdapat perbedaan antara apa yang di inginkan dengan kenyataan. Kepuasan kerja itu sendiri merupakan faktor yang dapat mempengaruhi kepuasa hidup seorang individu. Hasil penelitian Judge \& Watanebe (1993), Robbins \& Kliewer (2000) dan Senter, et al. (2010) menemukan bahwa terdapat korelasi positif antara kepuasan kerja dan kepuasan hidup. Selain itu, terdapat hubungan yang kuat antara pekerjaan dan kepuasan hidup dan dapat terjadi sebaliknya atau seorang karyawan yang tidak puas dengan pekerjaannya, tetapi puas dengan hidupnya secara keseluruhan akan melakukan pekerjaan dengan lebih baik.

\section{KAJIAN TEORI DAN PENGEMBANGAN HIPOTESIS \\ Konflik Antar pribadi (Interpersonal Conflict)}

Kreitner dan Kinicki (2005) mengemukakan bahwa konflik kepribadian merupakan pertentangan antar pribadi yang didorong oleh ketidaksukaan atau ketidaksepakatan yang sifatnya pribadi. Konflik kepribadian yang kronis dimulai dengan kemarahan yang tampaknya tidak signifikan.

McShane and Glinow (2008) "conflict is the process in which one party perceives that its interests are being opposed or negatively affected by another party". Sejalan dengan defenisi ini, Luthans (2008) mengemukakan bahwa konflik antar pribadi muncul ketika seorang individu berpersepsi negatif kepada individu lainnya atau selalu menguhubungkan penyebab konflik kemasalah kepribadian individu lainnya.

Sedangkan menurut Raeva, et al. (2008) bahwa, "Defined interpersonal conflict as: a dynamic process that occurs between interdependent parties as they experience negative emitional reactions to perceived diasagrements and interferences with attainment of their goals". Ketika seorang karyawan mengalami reaksi emosional negatif akan bertindak tidak rasional terhadap rekan kerja lainnya. Hal ini di pertegas oleh Slocum and Hellriegel (2007) "Interpersonal conflict occurs when two or more individuals perceive that their attitudes, behaviors, or preferred goals are in opposition”. Karena itu, menurut Henry (2009) sebagian besar orang mengharapkan satu perselisihan kepribadian. Perselisihan ini dapat berlangsung dalam bentuk pendapat berlawanan yang berhubungan dengan karakteristik personal anggota kelompok atau mengabaikan tujuan organisasi apapun untuk menimbulkan rasa tidak suka anggota kelompok tertentu. Hal tersebut dapat diakibatkan oleh interaksi seorang individu dengan tugasnya dan intraksi dengan individu lainnya dalam organisasi apapun yang istilahkan dengan task conflict dan relationship conflict (Henry, 2009). Konflik hubungan (relationship conflict) berkaitan dengan 
hubungan antar personal (Robbins dan Judge, 2008), sedangkan konflik tugas (task conflict) berhubungan dengan muatan dan tujuan pekerjaan. Menurutnya bahwa konflik tugas dapat menyebabkan ketegangan, perlawanan, kebencian dan ketidakbahagiaan di antara anggota organisasi dan keengganan untuk bekerjasama di masa yang akan datang. Namun demikian, konflik tidak selamanya berdampak destruktif (negatif), tetapi juga berdampak kontruktif baik terhadap karyawan maupun organisasi. Berkaitan dengan hal ini, menurut Newstrom (2002) bahwa konflik (misalnya konflik interpersonal) dapat berdampak positif dan negatif. Lebih lanjut dijelaskan, dampak positif dari konflik adalah (1) Orang-orang dalam suatu organisasi didorong untuk mencari pemecahan masalah dan melakukan pendekatan-pendekatan yang terbaik sehingga akan meningkatkan kreativitas dan banyak mencoba hal-hal baru; dan (2) Dapat menanggulangi masalah-masalah yang terpendam namun sangat perlu untuk diselesaikan, maka konflik di masa yang akan datang dapat dihindarkan.

Menurut McShane dan Glinow (2008) bahwa sumber konflik interpersonal meliputi: perbedaan personal (differentiations), masalah komunikasi (comunication problems), ketergantungan tugas (task interdependences), sumberdaya langkah (scarce resources), kerancuan aturan (ambiguous rules), dan ketidakcocokan tujuan (imcompatible goals). Sedangkan menurut Luthans (2008) konflik interpersonal bersumber dari: 1) Perbedaan personal, (Personal differences), 2) Defisiensi informasi/masalah komuikasi ((Information deficiency), 3) Ketidaksesuaian peran (Role incompatibility), 4) Tekanan Lingkungan (Environmental stress). Lebih lanjut dijelaskan, bahwa setiap orang mempunyai latar belakang yang unik dikarenakan proses pertumbuhan, tradisi keluarga, budaya, dan proses sosialisasi. Menurutnya bahwa karena setiap orang memiliki latar belakang keluarga, pendidikan atau pelatihan (training), dan nilai yang berbeda, maka hal ini dapat menjadi sumber utama konflik antar pribadi. Kepribadian itu sendiri menurut Luthans (2008) adalah bagaimana orang memengaruhi orang lain dan bagaimana mereka memahami dan memandang dirinya atau keseluruhan cara bagaimana seorang individu bereaksi dan berinteraksi dengan individu lainnya. Sejalan dengan hal ini, menurut McShane dan Glinow (2008) Perbedaan personal (differentiation) yaitu konflik antar pribadi yang disebabkan oleh perbedaan nilai dan perbedaan kepercayaan (persepsi) sehubungan dengan keunikan latar belakang, pengalaman atau pelatihan. Berdasarkan pendapat Luthans (2008) dan McShane \& Glinow (2008) maka dapat disimpulkan bahwa indikator perbedaan personal dapat dilihat dari perbedaan nilai dan perbedaan persepsi.

Menurut McShane dan Glinow (2008) bahwa, Nilai adalah keseimbangan, kepercayaan (anggapan) yang panjang tentang pentingnya berbagai bentuk situasi, sebagai petunjuk keputusan-keputusan dan tindakan seseorang). Sedangkan persepsi adalah "the process of receiving information about and making sense of the world around us (McShane dan Glinow (2008)". Jadi, persepsi merupakan respon individu terhadap lingkungan sekitar atau persepsi merupakan interpertasi unik dari satu situasi, bukan rekaman situasi.

McShane dan Glinow (2008), Slocum dan Herlieger (2007), dan Brumels dan Beach (2008) mengemukakan bahwa ambiguitas peran (role ambiguity) terjadi ketika suatu posisi tertentu adalah samar-samar, belum jelas, atau tidak jelas, terdiri dari tanggung-jawab peran berlawanan, dan dihubungkan dengan persyaratan yang buruk atau dapat didefinisikan sebagai kinerja buruk, dan tidak konsistennya disiplin atau evaluasi.

Berdasakan uraian di atas, maka kon flik interpersonal perlu diketahui dan kelola. Menurut McShane dan Glinow (2008) konflik interpersonal perlu dikelola dengan cara: 1) Collaborating adalah mencoba menemukan penyelesaian yang menguntungkan kedua belah pihak yang terlibat konflik melalui problem solving; 2) Avoiding adalah mencoba untuk menghindari situasi konflik. Misalnya beberapa karyawan akan mengatur kembali tempat kerja atau tugasnya untuk meminimalkan interaksi dengan co-workers; 3) Competing adalah mencoba untuk memenangkan konflik. Gaya ini lebih mengarah pada orientasi win-lose karena berada pada tingkat assertive yang tinggi dan cooperative yang rendah; 4) Accomodating adalah gaya yang manajemen konflik yang mempertimbangkan kedua pihak yang terlibat. Jadi tidak mementingkan kepentingan diri sendiri; dan 5) Compromising adalah mencoba 
untuk mencari jalan tengah, di mana setiap pihak memiliki sesuatu yang ditawarkan dan diterima.

\section{Work-Family Conflict}

Konflik di lingkungan organisasi akan mempengaruhi konflik di lingkungan keluarga dan sebaliknya. Hal ini sesuai dengan pendapat yang dikemukakan oleh Frone, et al., 1992 dikutip oleh Huffman (2004) bahwa pekerjaan bisa mengganggu keluarga dan keluarga bisa mengganggu pekerjaan. Huffman (2004) menyatakan bahwa gangguan antara kedua domain (pekerjaan dan keluarga) secara alami saling mempengaruhi. Sebagai contoh, satu karyawan dapat bekerja dengan jam kerja yang panjang akan mengganggu tanggung jawabnya di rumah. Dengan demikian, seorang yang bekerja lebih lama atau bekerja di luar jam kerja standar (overtime) akan merasakan tekanan (stress) yang dapat mempengaruhi konflik di domain keluarga, dan sebaliknya konflik atau tekanan di dalam keluarga akan mempengaruhi konflik di tempat kerja. Dengan demikian konflik di tempat kerja seperti misalnya keadilan distribusi, hubungan antar pribadi, informasi, dan prosedur kerja akan mempengaruhi reaksi psikis maupun fisik seorang karyawan yang pada gilirannya menimbulkan konflik diantaranya konflik interpersonal. Rekasirekasi tersebut berhubungan dengan stres (tekanan) pada ke-2 domain (pekerjaan dan keluarga). Hal tersebut menunjukan bahwa keadilan organisasional sangat menentukan tensi konflik di kedua domain (pekerjaan dan keluarga). Dengan kata lain, jika terjadi ketidakadilan di tempat kerja, maka menimbulkan konflik di tempat kerja yang pada gilirannya berdampak positif terhadap konflik keluarga (work-family conflict). Selain itu, menurut Mathis, et al. (2007) bahwa konflik keluarga (work-family conflict) akibat dari intervensi pekerjaan (work interference family) berpengaruh negatif terhadap kepuasan kerja.

Menurut Dierdorff \& Ellington (2008) dan Greenhaus, et al. (2006) bahwa: "defined Work-family conflict as "a form of interrole conflict in which the role pressures from the work and family domains are mutually incompatible in some respect". Selanjutnya, Menurut Greenhaus, et al. (2006) bahwa terdapat tiga jenis work-family conflict yaitu:
(1) Time based conflict, yaitu menyangkut bagaimana menyeimbangkan waktu untuk keluarga, waktu untuk istirahat dan membagi waktu atau waktu untuk aktivitas lain yang tidak berkaitan dengan kerja; (2) Strain based conflict yaitu penyebab stres (tekanan) karena adanya konflik yang meluap dari satu ranah ke ranah yang lain. Misalnya masalah rumah tangga, kesulitan keuangan, dan kehilangan orang yang dicintai; dan (3) Role behavior conflict yaitu terjadi ketika sikap seseorang diharapkan melakukan hal berbeda di tempat kerja dan di luar tempat kerja. Orang yang bertindak secara logis dan hubungan antar pribadi di tempat kerja memiliki kesulitan untuk mengubah gaya perilakunya ke gaya perilaku yang lebih melibatkan perasaan dalam kehidupan pribadinya.

\section{Pengertian Stres}

Respon seorang individu terhadap stresor tergantung pada kepribadian, sumber-sumber daya yang ada untuk membantu mereka mengatasi, dan konteks dimana stres terjadi (Daft, 2006). Sementara itu, dikemukakan oleh Ivancevich, et al. (2007) bahwa dari perspektif orang biasa, stres dapat digambarkan sebagai perasaan tegang, gelisah atau khawatir, semua perasaan merupakan manifestasi dari pengalaman stres, suatu terprogram yang kompleks untuk mempersepsikan ancaman yang dapat menimbulkan hasil yang postif maupun negatif. Hal tersebut berarti bahwa stres dapat berdampak negatif atau positif terhadap psikologis dan fisiologis (Robbins \& Judge, 2008; dan McShane \& Glinow, 2008).

Menurut McShane and Glinow (2008) bahwa "Stress is an adaptive response to a situation that is perceived as challenging or threatening to the person's well-being". Sedangkan menurut Brillhart (2004) mendefinisikan stres sebagai respon adaptif seseorang terhadap stimulus yang menempatkan permintaan fisik atau psikologis yang terlalu berlebihan terhadap orang itu. Selanjutnya, dikemukakan oleh Robbins dan Judge (2008) bahwa stres adalah suatu kondisi dinamis dimana seseorang individu dihadapkan pada peluang, tuntutan dan sumber daya yang terkait dengan apa yang dihasratkan oleh individu yang hasilnya dipandang tidak pasti dan penting. 
Berdasarkan definisi tersebut di atas, jelas bahwa setiap orang pasti mengalami stres, baik di luar organisasi maupun di dalam organisasi apapun. Dengan kata lain, setiap orang tidak dapat menghindari stres, untuk itu karyawan maupun pimpinan berkewajiban mengelolanya dengan baik. Ketika seorang karyawan maupun manajer mampu mengelola stresnya dengan baik, maka konsekuensinya adalah fungsional (positif), sebaliknya jika mengabaikan stres yang muncul, konsekuensinya adalah negatif terhadap individu maupun organisasi. Jadi, stres tidak hanya berdampak negatif, tetapi juga berdampak positif pada seseorang. Hal tersebut sesuai dengan pendapat yang dikemukakan oleh Hans Selye dikutip oleh Kreitner dan Kinicki (2005), dan Luthan (2008) mengemukakan bahwa stres bukanlan sekedar ketegangan syaraf, stres dapat memiliki konsekuensi yang positif, stres bukanlah sesuatu yang harus dihindari, dan tidak adanya stres sama sekali adalah kematian.

Menurut Ivancevich, et al. (2007) bahwa efek dari stres banyak dan bervariasi. Beberapa efek, tentu saja bersifat positif, seperti motivasi diri dan stimulasi untuk memuaskan tujuan individu. Sedangkan McShane dan Glinow (2008) mengemukakan bahwa stres dapat menimbulkan konsekuensi negatif terhadap tubuh manusia (physiological). Pada level stres tinggi senantiasa diiringi oleh berbagai masalah kesehatan tubuh, di antaranya adalah tekanan darah tinggi, tingkat kolesterol yang tinggi, dan sakit jantung. Sementara itu, dampak negatif psikologis (psychological) meliputi, ketidakpuasan kerja, tidak mood, dan depresi. Dengan demikian, seorang individu yang mengalami stres (distress) akan merasakan ketegangan yang berlebihan, sedangkan orang yang mengalami stres (eustress) akan mengalami sedikit ketegangan (McShane dan Glinow, 2008). Perbedaan kedua situasi tersebut mengindiksikan bahwa orang yang stres (distress) tersimpan di dalam dirinya energi tegang sedangkan orang yang stres (eustress) tersimpan di dalam dirinya energi tenang. Karena itu stres perlu dikelola. Terdapat 2 pendekatan menurut Robbins dan Judge (2008) yaitu 1) Pendekatan Individual. Karyawan dapat memikul tanggung jawab pribadi untuk mengurangi tingkat stresnya. Strategi individu yang telah terbukti efektif mencakup pelaksanaan teknik-teknik manajemen waktu, meningkatkan latihan fisik, pelatihan pengenduran (relaksasi), dan perluasan jaringan dukungan sosial; dan 2) Pendekatan organisasi. Beberapa faktor yang menyebabkan stres terutama tuntutan tugas dan peran dan struktur organisasi dikendalikan oleh manajemen. Dengan demikian faktor-faktor ini dapat dimodifikasi atau diubah. Strategi yang mungkin perlu dipertimbangkan oleh pihak manajemen adalah perbaikan seleksi personil, penempatan, penetapan sasaran yang realistis, perancangan ulang pekerjaan, peningkatan keterlibatan karyawan, perbaikan komunikasi organisasi, dan penegakan program kesejahteraan perusahaan.

Ada beberapa teknik pengukuran stres, salah satunya adalah dengan menggunakan Respon adaptif seseroang dapat dilihat dari rekasi psikologis (emosinya) da reaksi fisik (physiological). PSQ (Perceived Stress Questionnaire) yang dikembangkan oleh Fliege, at al. (2005) yang dimensi pengukurannya meliputi stress reaction dan perceived environmental stressor atau demands. Dijelaskan juga oleh Fliege et al. bahwa demands merupakan tuntutan lingkungan kerja, sedangkan stress reaction merupakan kekhawatiran, ketegangan, dan kegembiraan yang dirasakan seseorang ditempat kerja.

\section{Kepuasan Kerja (Job Satisfaction)}

Menurut Franzcp, et al. (2008) kepuasan kerja adalah perasaan dari pemenuhan dan kebanggaan yang dirasakan oleh orang-orang dalam menikmati pekerjaannya serta melakukannya dengan baik. Sedangkan menurut menurut Wexley dan Yukl (2005) bahwa kepuasan kerja merupakan generalisasi sikap-sikap terhadap pekerjaannya yang didasarkan atas aspek-aspek pekerjaannya bermacam-macam.

Menurut McShane and Glinow (2008) bahwa "job saticfaction, a person's evaluation of his or her job and work context. Sedangkan Mathis dan Jackson (2006) menjelaskan bahwa kepuasan kerja adalah keadaan emosional positif yang merupakan hasil dari evaluasi pekerjaan seseorang. Definisi-definisi ini pada dasarnya melihat kepuasan kerja sebagai sebuah perilaku dan kognitif orang-orang di tempat kerja terhadap pekerjaannya. Perilaku dan kognitif merupakan bagian dari komponen sikap (Robbins dan Judge, 2008). Karena itu, 
kepuasan kerja sangat berkaitan dengan komponen-komponen tersebut. Ketika reaksi seorang individu secara kongnitif, afektif, dan evaluatif terhadap pekerjaannya, maka pada saat yang sama menimbulkan kepuasan atau ketidakpuasan kerja. Ini berarti, pekerjaan dapat menyebabkan kepuasan dan ketidakpuasan seorang individu. Menurut Ho, et al. (2009) bahwa kepuasan kerja adalah sikap positif atau negatif yang dimiliki seorang karyawan tentang pekerjaannya atau beberapa aspek spesifik pekerjaan, dan merupakan pandangan internal seorang individu. Sedangkan menurut Gibson, et al. (2006) kepuasan kerja adalah ekspresi kesehatan seorang individu yang berhubungan dengan tugas yang diberikan (Luthans (2008) memberikan definisi komprehensif mengenai kepuasan kerja yang meliputi reaksi atau sikap kognitif, afektif, dan evaluatif dan menyatakan bahwa: "a pleasurable or positive emotional state resulting from appraisal of one job experience". Dikemukakan juga oleh Luthans (2008) bahwa: "Job Satisfaction is a result of employees, perception of how well their job provides those thing that are viewed as important". Sejalan dengan pendapat tersebut dikemukakan oleh Daft (2006) bahwa kepuasan kerja (job satisfaction) adalah sebuah sikap positif terhadap pekerjaan seseorang. Sedangkan menurut Robbins dan Judge (2008) bahwa: "positive feelings about one's job based on one's evaluation of the characteristics of the job". Sejalan dengan hal tersebut, menurut Daft (2006) bahwa secara umum orang-orang yang mengalami sikap ini ketika pekerjaan mereka sesuai dengan kebutuhan-kebutuhan dan kepentingan mereka, ketika kondisi kerja dan penghargaan (seperti gaji) memuaskan, dan ketika para karyawan menyukai rekan-rekan kerja mereka.

Akehurst, et al. (2009) mengemukakan bahwa seseorang dengan kepuasan kerja tinggi akan menyukai pekerjaannya secara umum, dimana seseorang merasakan diperlakukan selayaknya dan percaya bahwa pekerjaan mempunyai banyak segi yang diinginkan. Sejalan dengan hal tersebut, George dan Jones (2008) menyatakan bahwa kepuasan kerja adalah kumpulan perasaan dan kepercayaan yang dimiliki setiap individu tentang pekerjaannya saat ini. Dengan demikian, kepuasan kerja seseorang tergantung pada selisih antara harapan, kebutuhan atau nilai dengan apa yang menurut pandangan atau persepsinya yang telah dicapai melalui pekerjaannya. Jadi, seorang akan merasakan kepuasan jika tidak ada perbedaan antara apa yang diinginkan dengan apa yang sesungguhnya terjadi, sebaliknya, apabila terdapat perbedaan antara apa yang diinginkan dengan kenyataan, maka seseorang akan merasakan ketidakpuasan (dissatisfaction).

Menurut Geoge dan Jones (2008) bahwa dimensi Kepuasan kerja adalah personaliti (personality), nilai (value), situasi pekerjaan (work situation), dan lingkungan sosial (social influence). Penjelasannya sebagai berikut: (1) Personality: merupakan cara pandang seseorang yang terbentuk karena perasaan, pikiran, dan keyakinan, meliputi: pemanfaatan kemampuan, prestasi kerja, kemajuan, kreativitas kerja, dan kemandirian dalam melaksanakan tugas; (2) Values: merupakan nilai-nilai kerja seseorang yang bersifat intrinsik maupun ekstrinsik, terdiri dari: imbalan, pengakuan, tanggungjawab, jaminan kerja, dan layanan sosial; (3) Work Conditions: merupakan situasi kerja yang terbentuk karena pekerjaan itu sendiri, rekan kerja, supervisor, bawahan dan kondisi fisik, terdiri dari: wewenang, hubungan dengan atasan, pengawasan teknis, keberagaman tugas, dan kondisi kerja; dan (4) Social Influence: merupakan pengaruh yang terbentuk karena rekan kerja, kelompok dan budaya organisasi, meliputi: aktivitas/kegiatan, kebijakan perusahaan, rekan kerja, nilai moral dan status.

\section{Kepuasan Hidup (Life Satisfaction)}

Menurut Rooks (2010) bahwa orang bereaksi berbeda dengan keadaan hidup yang sama sebagai hasil dari masing-masing skema kognitif dan keyakinan adalah tidak semata-mata indikator obyektif sosial (misalnya, pekerjaan, tingkat pendapatan) yang mendefinisikan kepuasan seseorang dengan hidupnya.

Shin dan Johnson (1978) mengemukakan bahwa, "defined life satisfaction as a global assessment of a person's quality of life according to his chosen criteria" (dikutip oleh Forgeard, et al. 2010). Oleh karena itu, menurut Forgeard et al. (2010) penilaian kepuasan hidup tergantung pada standar individu yang telah ditentukan untuk diri seorang individu. Individu dengan kondisi objektif sama bisa menilai 
kehidupannya menjadi lebih memuaskan (more satisfying) atau kurang memuaskan (less satisfying), masalah yang telah menyebabkan banyak orang untuk mengadvokasi penggunaan pengukuran obyektif kesejahteraan (subjective well-being), yang mana life satisfaction dapat diukur dengan menggunakan skala kepuasan hidup (satisfaction with life scale).

Menurut Justina (2011) bahwa, life satisfaction as a general assessment of the quality of one's life as a whole constitutes an overarching, multi-facetted, and multi-domainencompassing concept. Lebih lanjut dijelaskan, kepuasan juga dapat dinilai sehubungan dengan aspek-aspek tertentu dari kehidupan seseorang, atau domain tertentu, sebagai contoh kepuasan finansial (kepuasan dengan kekayaan seseorang dan situasi pendapatan), kepuasan kerja, kepuasan dengan kesehatan seseorang, atau kepuasan dengan pernikahan seseorang dan kehidupan keluarga. Justina (2011) mengusulkan tujuh domain kehidupan sebagai kontribusi utama untuk kualitas hidup (quality of life): kesejahteraan materi (material well-being), kesehatan (health), produktivitas (productivity), keharmonisan keluarga/suami-isteri (intimacy), keamanan (safety), masyarakat (community), dan kesejahteraan emosional (emotional wellbeing). Namun, menurut Justina selain domain ini ada juga lebih tradisional yaitu struktur dan organisasi pemerintahan (pemerintah, demokrasi, kebijakan), pelayanan pemerintah (kesejahteraan dan pelayanan masyarakat), atau pemeliharaan kehidupan (pekerjaan rumah, pemeliharaan rumah). Kepuasan hidup mencerminkan penilaian secara keseluruhan dari kehidupan pada umumnya, sedangkan domain kepuasan merupakan, analogi, penilaian dari sebuah domain hidup tertentu. Beberapa peneliti percaya bahwa kebahagiaan (happiness) dengan kepuasan hidup (life satisfaction) secara keseluruhan dapat dibangun dengan menggunakan informasi tentang berbagai domain kepuasan, misalnya, dengan menggunakan ukuran obyektif kualitas hidup (Comprehensive Quality of Life Scale) (Justina, 2011). Selanjutnya, kepuasan hidup berkaitan atau dapat dikur dengan kulaitas hidup (quality of life). Pengukuran life satisfaction merupakan evaluasi kognitif dari kualitas hidup (quality of life) seseorang secara keseluruhan. Karena itu, quality of life perlu didefinisikan sehingga tidak tumpang-tindih dalam penggunaan kedua isti- lah yakni life satisfaction dan quality of life (QoL). Menurut Mazaheri (2010) bahwa quality of life adalah perasaan dari kepuasan hidup secara keseluruhan, sebagaimana ditentukan oleh individu yang hidupnya waspada secara mental sedang dievaluasi dan orang lain, lebih disukai orang-orang dari luar situasi hidup orang itu, juga harus setujui bahwa kondisi hidup individu tidak mengancam hidupnya dan memadai dalam memenuhi kebutuhan dasar individu. Selanjutnya Mazaheri (2010:89) mengutip World Health Organisation (WHO): defined "Quality Of Life (QOL)" as an individual's perception of their position in life in the context of the culture and value systems in which they live and in relation to their goals, expectations, stadards and concerns.

Pavot dan Diener (1993) mengemukakan bahwa: "life satisfaction is a conscious cognitive judgment of one's life in which the criteria for judgment are up to the person". Lebih lanjut dikatakan bahwa, kepuasan hidup dapat di ukur melalui skala hidup atau disebut dengan satisfaction with life scale (SWLS), yaitu: (1) In most ways my life is close to my ideal; (2) The conditions of my life are excellent; (3) I am satisfied with my life; (4) So far I have gotten the important things I want in life; and (5) If I could live my life over, I would change almost nothing.

Menurut McMillan (2011) bahwa define life satisfaction as a cognitive, global evaluation of an individual's life as a whole based on a set of pre-determined standards. Sedangkan menurut Veenhoven (1991) bahwa, kepuasan hidup adalah tingkat pada jastifikasi seorang individual mengenai kualitas secara keseluruhan dari keselurahan kehidupannya yang menyenangkan). Kulaitas hidup (quality of life) seorang individu secara keseluruhan erat kaitannya dengan kesejahteraan (wellbeing), karena wellbeing menunjukkan sesuatu yang dalam kondisi baik (Samman, 2007). Lebih lanjut dikemukakan bahwa Wellbeing itu dibagi menjadi dua bagian yaitu subjetive wellbeing dan objective wellbeing. Subjective Wellbeing (SWB) memiliki tiga komponen: komponen kognitif, affec negative dan affec positive. Lebih lanjut dijelaskan njuga bahwa, jumlah lebih besar efek positif daripada efek negatif merupakan gambaran dari kebahagian (happiness). 
Veenhoven (1991) Subjective quality of life atau Subjective Wellbeing (SWB) adalah bagaimana orang menghargai hidup mereka secara pribadi. Misalnya, seberapa aman mereka berpikir pendapatan mereka, bagaimana mereka merasa aman di jalan, seberapa puas mereka dengan kesehatan dan pendidikan dan lain-lain. Subjektif awal berarti bahwa kriteria untuk penilaian dapat bervariasi dari orang ke orang. Dalam hal ini, standar tidak eksplisit, dan penilaian eksternal tidak mungkin. Sedangkan, Objective quality of-life atau Objective Wellbeing (OWB) adalah sejauh mana kondisi hidup memenuhi kriteria yang diamati dari kehidupan yang baik, seperti: jaminan pendapatan untuk semua orang, keselamatan di jalan, perawatan kesehatan yang baik, pendidikan, dan lain-lain. Dalam konteks ini objektif awalan mengacu pada cara pengukuran. Pengukuran didasarkan pada kriteria eksplisit dari keberhasilan yang dapat diterapkan oleh pihak luar yang tidak memihak. Menurut Samman (2007) bahwa, kita tidak dapat memisahkan pengukuran dari life satisfaction dan kebahagian (happiness), karena itu patut dipertimbangkan kedua hal tersebut. Samman (2007) mengutip pendapat Cummins kriteria tambahan untuk pemilihan domain kepuasan kaitannya dengan hidup, yaitu: (1) domain harus mampu memberikan kontribusi variasi-variasi unik untuk memprediksi $\mathrm{Ke}$ hidupan secara keseluruhan sebagaimana ditentukan oleh pengurangan domain potensial terhadap keseluruhan kepuasan dengan indikator kehidupan; dan (2) bahwa mereka harus dapat diwakili baik secara objective dan subjective, dan dalam penelitiannya menggunakan area (domain) untuk mengukur kepuasan kerja secara keseluruhan, yang terdiri dari: (1) Kesejahteraan materi (material welbeing) meliputi: makanan, perumahan, dan pendapatan; (2) Kesehatan dan produktivitas meliputi: Kesehatan dan pekerjaan rumah; (3) Keamanan dan keintiman meliputi: Jaminan sosial, kehidupan keluarga, dan pertemanan, suami/isteri; (4) Komunitas meliputi: kehidupan sosial, pendidikan, dan pekerja sukarela; dan (5) Agama meliputi: Peribadatan, waktu libur, kehidupan yang panjang, politik, keseimbangan kehidupan-kerja, waktu senggang, dan perawatan anak.

\section{PENGEMBANGAN HIPOTESIS}

Pengaruh Konflik Interpersonal (Interpersonal Conflict) terhadap Stres Kerja (Work Stress)

Menurut Luthans (2008) bahwa konflik antar peribadi dapat dilihat dari: personal differences, information deficiency, role incompatibility, dan inveronmental stress. Salah satu sumber stres adalah persepsi negatif seseorang terhadap individu lain, karena itu menurut McShane dan Glinow (2008) konflik kerja akibat dari hubungan antar pribadi dapat meningkatkan stres kerja seseorang atau seorang karyawan akan mengalami stres negatif (distress) yang bersumber dari hubungan antarpersonal (interpersonal stressors).

Menurut McShane and Glinow (2008) bahwa "Stress is an adaptive response to a situation that is perceived as challenging or threatening to the person's well-being". Pernyataan ini mengisyaratkan bahwa dalam merespon stresor atau sumber-sumber stres (misalnya, konflik antar pribadi) sangat bergantung pada kepribadian, sumber-sumber daya yang dimilikinya untuk membantunya mengatasi dan mengelola stres yang terjadi.

Stres interpersonal (interpersonal stressors) juga dapat berwujud pelecehan seksual, kekerasan di tempat kerja, gertakan atau kejadian-kejadian lain yang memungkinkan timbulnya stres bagi diri karyawan. Penyebab stres karena adanya interaksi antar staf atau antara staf dan supervisi (interpersonal stressors) dapat menyebabkan ketidakpuasan kerja. Dengan demikian, konflik antar pribadi adalah stresor atau penyebab munculnya stres seseorang di tempat kerja dan dapat berpengaruh positif terhadap stres kerja. Dengan kata lain, konflik merupakan salah satu sumber munculnya stres kerja. Hal ini diperkuat dengan hasil penelitian Judge dan Collquit (2004), Ahsan, et al. (2009), Hershcovis dan Barling (2007), dan Ito and Brotheridge (2009) bahwa konflik antar pribadi (interpersonal conflict) berpengaruh positif terhadap stres kerja (work stress).

Berdasarkan uraian di atas, maka dirumuskan hipotesis penelitian sebagai berikut:

$\mathrm{H}_{1}$ : Konflik Interpersonal (Interpersonal Conflict) berpengaruh positif terhadap Stres Kerja. 


\section{Pengaruh Work-Family Conflict terhadap Stres Kerja}

Greenhaus dan Beutell, 1985 dikutip oleh Grzywacz, et al. (2007) menyatakan bahwa Work-Family Conflict secara umum mengacu pada tingkatan pada pekerjaan dan tanggung jawab yang berhubungan dengan keluarga yang mengganggu satu sama lain serta secara tipikal didefinisikan sebagai "satu jenis dari konflik antar-peran yang terjadi sebagai hasil tekanan peran tidak kompatibel dari pekerjaan dan domain keluarga". Dengan demikian, maka konflik keluarga akan mempengaruhi stres kerja.

Menurut Grzywacz, et al. (2007) workfamily conflict dan family-work conflict adalah secara luas mengakui bahwa sumber utama stressor atau tekanan dalam pekerjaan dan memiliki hubungan negatif diantara beberapa orang, psikologis, dan hasil organisasional. Dengan demikian konflik keluarga (workfamily conflict) dapat menyebab seorang individu dalam kelompok organisasi mengalami stres kerja. Karena stres kerja pada dasarnya respon adaptif seseorang terhadap lingkungan baik lingkungan organisasi maupun diluar organisasi. Hal ini juga dipertegas oleh Byron (2005), Mesmers \& Viswesvaran (2005), dan Grzywacz, et al. (2007) bahwa Work-family conflict adalah hubungan dua arah, seperti pekerjaan dapat menganggu keluarga (work-tofamily conflict) atau pekerjaan dapat menimbulkan konflik keluarga dan keluarga dapat menganggu pekerjaan (family-to-work conflict.) Ini berarti work-family conflict adalah salah satu sumber stres yang dapat mempengaruhi secara positif stres kerja seseorang ditempat kerja.

Terdapat beberapa hasil penelitian yang mendukung pernyataan bahwa work family conflict berpengaruh positif terhadap stres kerja seorang individu yakni: Hammer, et al. (2004), dan Shimazu et al. (2010). Dalam penelitian Shimazu (2010) menjelaskan bahwa konflik kerja dan konflik keluarga secara bersamaan dapat menganggu atau mempengaruhi secara positif stres kerja.

Berdasarkan uraian di atas, maka dirumuskan hipotesis penelitian sebagai berikut: $\mathrm{H}_{3}$ : Work-family conflict berpengaruh positif terhadap Stres kerja.

\section{Pengaruh Konflik Interpersonal terhadap Kepuasan Kerja}

Istilah interpersonal conflict digunakan untuk menunjukan perselisihan paham bahwa sebagian besar orang mengharapkan satu persilisihan kepribadian. Persilisihan ini dapat berlangsung dalam bentuk pendapat berlawanan yang berhubungan dengan karakteristik personal dari satu anggota kelompok atau mengabaikan tujuan organisasi apapun untuk menimbulkan rasa tidak suka satu anggota kelompok tertentu.

Menurut Luthan (2008) bahwa, kepuasan Kerja adalah hasil dari presepsi karyawan mengenai seberapa baik pekerjaan mereka memberikan hal yang dinilai penting. Seorang karyawan atau individu dalam kelompok organisasi memiliki presepsi yang negatif atau menganggap bahwa orang lain dalam kelompok yang sama sedang atau akan menghalangi tujuannya, maka ketidakpuasan akan tumbuh dalam dirinya dan sebaliknya ketika seorang karyawan memiliki presepsi positif maka akan merasakan kepuasan. Hal ini juga dipertegas oleh Robbins \& Judge (2008) bahwa, kepuasan kerja adalah suatu perasaan positif tentang pekerjaan seseorang yang merupakan hasil dari sebuah evaluasi karakteristiknya. Seseorang dengan tingkat kepuasan kerja tinggi perasaan-perasaan positif tentang pekerjaan tersebut, sementara seorang yang tidak puas memiliki perasaan negatif tentang pekerjaan tersebut.

Menurut Ghazzawi (2008) bahwa personality seseorang mempengaruhi seberapa besar keinginan individual berpikir dan merasakan tentang satu pekerjaan baik secara positif atau secara negatif. Hal ini menunjukan bahwa, konflik antarpribadi yakni konflik yang pada dasarnya terjadi ketika satu pihak merasakan tujuannya dihalangi oleh pihak lain, maka perasan negatif tentang satu pekerjaan dapat menimbulkan ketidakpuasan kerja. Hal ini karena, presepsi tentang sebuah pekerjaan berhubungan interaksi antar individu yang satu dengan lainnya, sedangkan presepsi negatif tentang pekerjaan dapat menimbulkan ketidakpusan dalam lingkungan kerjanya.

Berdasarkan penjelasan diatas dapat disimpulkan bahwa, semakin tinggi konflik antarpribadi maka akan berpengaruh negatif terhadap kepuasan kerja. Dengan kata lain 
konflik antarpribadi berdampak negatif ketika tanggapan atau presepsinya tetap bertahan pada perasaan negatif terhadap lingkungan kerjanya. Sejalan dengan hal ini, hasil penelitian Bradford, et al. (2001), Dreu (2003), Median, et al. (2005) Khan, et al. (2009) yang menunjukan bahwa konflik antar pribadi (konflik tugas dan konflik hubungan) berhubungan negatif dengan kepuasan kerja karyawan.

Berdasarkan uraian di atas, maka dirumuskan hipotesis penelitian sebagai berikut:

$\mathrm{H}_{2}$ : Konflik Antar Pribadi berpengaruh negatif terhadap Kepuasan kerja.

\section{Pengaruh Work Family Conflict terhadap Kepuasan Kerja}

Konflik juga terjadi diluar organisasi yang pada gilirannya akan mempengaruhi konflik seseorang atau karyawan ditempat kerjanya. Greenhaus dan Beutell dikutip oleh Huffman (2004), Mckee (2007) menyatakan bahwa, " $a$ form of interrole conflict in which the role pressures from the work and family domains are mutually incompatible in some respect". Pendapat yang serupa dikemukakan oleh Grzywacz, et al. (2007) bahwa seseorang yang mengalami konflik peran dimana perannya mengalami konflik akibat dari pekerjaan atau tempat kerja dan lingkungan keluarga yang tidak kompatibel.

Seseorang dengan tingkat kepuasan kerja tinggi perasaan-perasaan positif tentang pekerjaan tersebut, sementara seorang yang tidak puas memiliki perasaan negatif tentang pekerjaan tersebut. Hal ini sejalan dengan pendapat Janazs dan Behson (2007) mengemukakan bahwa, Walaupun konflik kerja dan konflik dilingkungan keluarga menurukan kepuasan kerja, akibat ini tidak terlalu berpengaruh bagi mereka yang memiliki toleransi terhadap ketidakpastian (konflik dalam organisasi dan konflik keluarga) dan toleransi terhadap ketidakpastian menurunkan hubungan antara interaksi pekerjaan dengan keluarga dan kepuasan kerja. Ini berarti konflik dilingkungan keluarga akan mempengaruhi secara negatif kepuasan kerja seseorang ditempat kerjanya. Hal ini sejalan dengan hasil penelitian yang dilakukan oleh Judge \& Colquitt (2004), Grandey, et al. (2005), Janazs $\&$ Behson (2007), and Mathis, et al. (2007) yang menunjukan bahwa work family conflict berpengaruh negatif terhadap kepuasan kerja (job satisfaction).

Berdasarkan uraian di atas, maka dirumuskan hipotesis penelitian sebagai berikut:

$\mathrm{H}_{4}$ : Work family conflict berpengaruh negatif terhadap Kepuasan Kerja.

\section{Pengaruh Stres Kerja (Work Stress) Terhadap Kepuasan Kerja (Job Satisfaction)}

Dampak stres bersifat positif, seperti motivasi diri dan stimulasi untuk memuaskan tujuan individu. Akan tetapi, beberapa konsekuensi stres bersifat merusak, kontraproduktif, dan bahkan secara potensial berbahaya. Karena itu, stres individu sangat mempengaruhi organisasi dalam mencapai tujuannya. Stres individu mungkin yang paling berpengaruh terhadap semua stresor yang ada karena merupakan perubahan yang tak pernah berhenti, dan merupakan bagian dari kehidupan saat ini.

Salah satu sumber stres adalah konflik antar pribadi atau stres akibat dari hubungan antar pribadi (interpersonal stressor). Dengan demikian, menurut McShane dan Glinow (2008) stres atau stresor yang berkaitan dengan pekerjaan yang meliputi: hubungan antar pribadi, pekerjaan/tugas (task) itu sendiri, hubungan antar personal, dan peran-peran kerja dapat mempengaruhi tingkat kepuasan dan ketidkpuasan kerja di tempat kerja . Dengan demikian, seseorang yang merasakan kepuasan kerja ketika pekerjaannya memiliki manfaat atau arti, dan ketidakpuasan kerja muncul pada saat harapannya berbeda dengan fakta yang ada.

Hubungan antara stres kerja dan kepuasan kerja terletak pada sumber stres itu sendiri. Artinya stres kerja merupakan stresor dari kepuasan kerja, dengan kata lain kepuasan atau ketidakpuasan kerja adalah dampak dari stres yang dilamai seorang individu. Dampak stres negatif (disters) seperti yang dikemukakan oleh McShane dan Glinow (2008) diantaranya adalah menurunnya kepuasan kerja (low job satisfaction). Karena itu, stres kerja dapat berpengaruh negatif terhadap kepuasan kerja seorang individu ditempat kerja. Hal ini sesuai dengan hasil penelitian Lian, et al. (2007) yang menjelaskan bahwa stres kerja berpengaruh negatif terhadap kepuasan kerja. Penelitian sejenis diteliti oleh Zhao dan Yamaguchi 
(2008) bahwa stres organisasional dan stres hubungan antar pribadi berhubungan negatif dengan kepuasan kerja. Hasil penelitian serupa oleh Ito and Brotheridge (2009:10), Arasly dan Tumer (2008), Franzcp, et al. (2008), Karadal, et al. (2008) dan Ahsan, et al., (2009) juga menemukan bahwa, stres kerja berpengaruh negatif terhadap kepuasan kerja (job satisfaction).

Berdasarkan uraian di atas, maka dirumuskan hipotesis penelitian sebagai berikut:

$\mathrm{H}_{5}$ : Stres kerja (work stress) berpengaruh negatif terhadap kepuasan kerja (job satisfaction).

\section{Pengaruh Kepuasan Kerja Terhadap Kepuasan Hidup}

Seorang pekerja atau karyawan akan merasakan kepuasan, jika tidak ada perbedaan antara apa yang diinginkan dengan apa yang sesungguhnya terjadi, sebaliknya, apabila terdapat perbedaan antara apa yang diinginkan dengan kenyataan, maka seseorang akan merasakan ketidakpuasan (dissatisfaction). Sejalan dengan ini, George dan Jones (2008) menyatakan bahwa kepuasan kerja adalah kumpulan perasaan dan kepercayaan (anggapan) yang dimiliki setiap individu tentang pekerjaannya saat ini). Namun demikian, kepuasan kerja atau ketidakpuasan kerja (disatisfaction) dapat berdampak langsung terhadap kepuasan hidup (life satisfaction). Hal ini sejalan dengan pendapat Rokks (2010) bahwa orang bereaksi berbeda dengan keadaan hidup yang sama sebagai hasil dari masing-masing skema kognitif dan keyakinan adalah tidak semata-mata indikator obyektif sosial (misalnya, pekerjaan, tingkat pendapatan) yang mendefinisikan kepuasan seseorang dengan hidupnya.

Selain hal di atas, menurut Justina (2011) bahwa kepuasan hidup sebagai penilaian umum kualitas hidup seseorang secara keseluruhan yang merupakan sebuah domain, multi aspek, dan meliputi multi konsep. Ini berarti seorang karyawan yang mempersepsikan tentang pekerjaan akan berpengaruh terhadap kepuasan hidupnya. Hasil penelitian Senter (2010), Lian, et al. (2007), dan Ghazzawi (2008) menunjukan bahwa kepuasan kerja berpengaruh positif terhadap kepuasan hidup.

Berdasarkan uraian di atas, maka dirumuskan hipotesis penelitian sebagai berikut:

$\mathrm{H}_{6}$ : Kepuasan Kerja berpengaruh Positif terhadap Kepuasan Hidup.

\section{METODE PENELITIAN}

Berikut ini akan diuraikan tentang jenis data dan sumber data, populasi dan sampel, Variabel penelitian dan operasionalisasi variabel dan metode analisis.

\section{Jenis Data dan Sumber Data}

Data yang dikumpulkan dalam penelitian ini adalah data primer dengan menggunakan kuesioner kepada PNS (responden). Sumber data merupakan pendapat dan persepsi dari setiap PNS golongan ruang III dan tidak menduduki jabatan sturuktural pada Sekretariat Jenderal Kementerian Pendidikan dan Kebudayaan terkait dengan konflik antar personal, konflik keluarga (work-family conflict), tingkat stres kerja, kepuasan kerja dan kepuasan hidup.

\section{Kerangka Pemikiran}

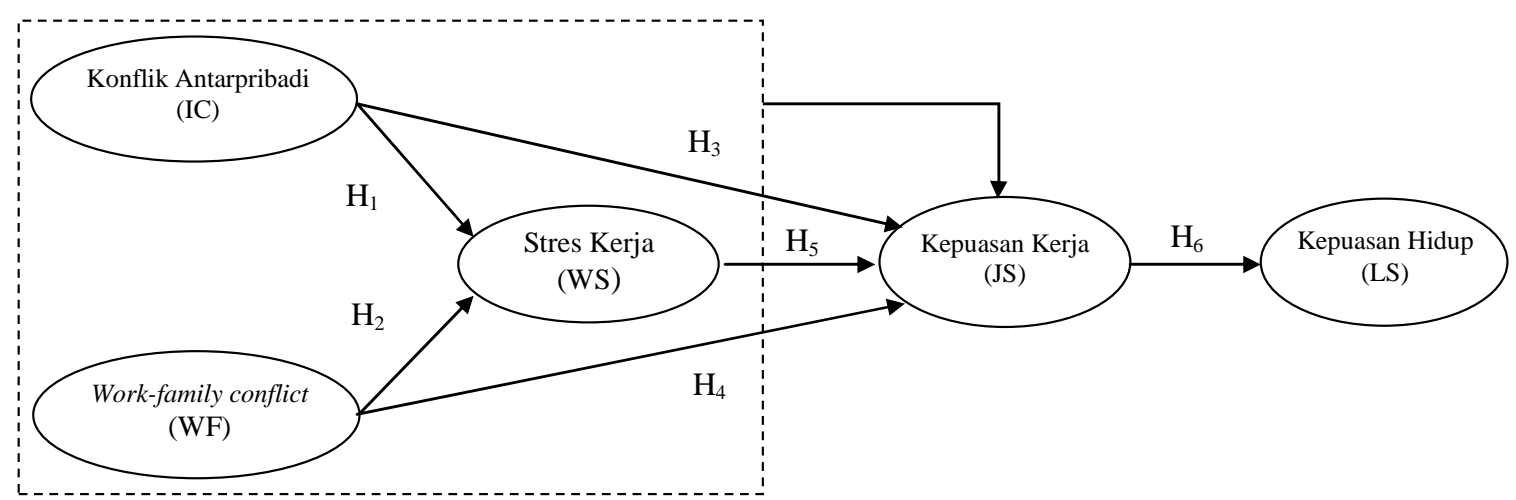

Gambar 1: Kerangka Pemikiran 


\section{Populasi dan Sampel}

Tabel 1: Jumlah Populasi dan Sampel

\begin{tabular}{llcc}
\hline No & \multicolumn{1}{c}{ Uraian } & Jumlah populasi & Ukuran Sampel \\
\hline 1 & Biro Umum & 120 & 47 \\
2 & Biro Perencanaan dan Kerja sama L.N & 96 & 37 \\
3 & Biro Keuangan & 72 & 28 \\
4 & Biro Kepegawaian & 214 & 83 \\
5 & Biro Hukum dan Organisasi & 125 & 49 \\
\hline \multicolumn{2}{c}{ Total } & $\mathbf{6 2 7}$ & $\mathbf{2 4 4}$ \\
\hline
\end{tabular}

Populasi dalam penelitian ini adalah Pegawai Negeri Sipil (PNS) pada Biro Umum, Biro Perencanaan dan Kerja Sama Luar Negeri, Biro Keuangan, Biro Kepegawaian, dan Biro Hukum dan Organisasi dengan masa kerja minimal 4 (empat) tahun yang tidak menduduki jabatan struktural.

Jumlah populasi target secara keseluruhan adalah sebanyak 627 orang. Metode atau teknik penarikan sampel yang digunakan adalah stratified random sampling, dengan alokasi proporsional. Metode ini digunakan karena responden (Pegawai Negeri Sipil) yang dijadikan sebagai populasi berada pada 5 biro atau populasinya bertingkat. Pengelompokan populasi berdasarkan unit (biro) kerja yang meliputi: Biro Umum, Biro Perencanaan dan Kerja sama Luar Negeri, Biro Keuangan, Biro Kepegawaian dan Biro Hukum dan Organisasi (Tabel 1).

\section{Variabel penelitian dan operasionalisasi variabel}

Konflik antarpribadi (IPC) adalah penilaian PNS tentang pertentangan antar pribadi yang muncul ketika berpersepsi negatif kepada pegawai lain Variabel ini diukur dengan menggunakan indikator yang dikemukakan oleh Luthans (2008) yaitu: 1) Perbedaan personal, (Personal differences), 2) Defisiensi informasi/masalah komuikasi ((Information deficiency), 3) Ketidaksesuaian peran (Role incompatibility), 4) Tekanan Lingkungan (Environmental stress). Jumlah instrumennya sebanyak 13 item pertanyaan.

Work-family conflict (WFC) adalah penilaian PNS tentang konflik antar peran (interrole) yang ditimbulkan akibat dari ketidakcocokan antara tuntutan peran di tempat kerja dengan keluarga. Variabel ini diukur dengan menggunakan indikator yang dikemu- kakan oleh Dierdorff \& Ellington (2008), dan Greenhaus, et al. (2006) yaitu: 1) Time based conflict, 2) Strain based conflict, dan 3) Role behavior conflict. Jumlah instrumennya sebanyak 11 item pertanyaan.

Stres Kerja (WKS) adalah penilaian PNS terhadap situasi yang dirasakan sebagai tantangan atau ancaman terhadap kesehatan fisik dan psikis. Variabel ini diukur dengan menggunakan indikator yang dikemukakan oleh Herbert, et al. (2005) yaitu: 1) Stress reaction, dan 2) Demands. Jumlah instrumennya sebanyak 12 item pertanyaan.

Kepuasan Kerja (JBS) adalah penilaian PNS tentang perasaan dan kepercayaan yang dimiliki seseorang terhadap pekerjaan yang dilakukan. Variabel ini diukur dengan menggunakan indikator dikemukakan oleh George dan Jones (2008) yaitu: 1) Kepribadian (Personality), 2) Nilai (Value), 3) Situasi Kerja (Work Situations), dan 4) Pengaruh Sosial (Social influences). Jumlah instrumennya sebanyak 23 item pertanyaan.

Kepuasan Hidup (LFS) adalah) adalah penilaian PNS secara keseluruhan terhadap kualitas hidup (quality of life) berdasarkan atas pikirannya sendiri dan berbagai pertimbangan dalam berbagai aspek kehidupan. Variabel ini diukur dengan menggunakan indikator dikembangkan oleh International Wellbeing GroupIwbG (2006) yaitu: 1) kesejahteraan materi, 2) kesehatan, 3) produktivitas, 4) keamanan, 5) keakraban, 6) kumunitas, dan 7) Kesejahteraan emosional. Jumlah instrumennya sebanyak 24 item pertanyaan.

Berdasarkan hasil uji validitas menunjukkan bahwa butir instrumen konflik interpersonal (IPC) nomor 2 tidak valid, work family conflict (WFC) nomor 4 dan 12 tidak valid, stres kerja (WKS) nomor 9, dan 12 tidak valid, kepuasan kerja (JBS) nomor 7 tidak valid, dan kepuasan hidup nomor 11 tidak 
valid, hal ini karena Corrected Item-Total Correlation (CITC) lebih kecil dari nilai $r$ tabel $\left(\mathrm{CITC}<\mathrm{r}_{\text {tabel=0.361 }}\right)$, sedangkan butir instrumen lainnya adalah valid karena Corrected ItemTotal Correlation lebih besar dari $r$ tabel. Sementara itu, kelima variabel tersebut dinyatakan reliabel karena nilai alpha cronbach's berada pada kisaran 0,7 sampai 0,9.

\section{Metode Analisis}

Penelitian ini adalah deskriptif dan verifikatif yang dilaksanakan melalui pengumpulan data primer di lapangan. Karen itu, metodenya adalah metode explanatory survey method dengan mengambil sampel dari suatu populasi dan menggunakan kuesioner sebagai instrumen pengumpulan data yang utama. Untuk menguji pengaruh antara variabel eksogen dan endogen, maka alat uji statistiknya adalah Structural Equation Modeling (SEM) dengan menggunakan program LISREL 8.80.

Berdasarkan pada paradigma penelitian yang diuraikan dalam kajian teori dan prinsip dasar SEM, maka pengaruh langsung antara variabel eksogen dan variabel endogen dapat digambarkan dalam bentuk diagram jalur secara keseluruhan (full model/hybrid model) seperti tampak pada gambar 1.

Hair, et al. (2009) menyatakan bahwa didalam SEM akan dilakukan uji kecocokan untuk memeriksa tingkat kecocokan antara data dengan model, validitas dan reliabilitas model pengukuran, dan siginifikansi koefisienkoefisien model struktural. Lebih lanjut dijelaskan, evaluasi terhadap tingkat kecocokan data dengan model dilakukan dengan melalui beberapa tahapan, yaitu: 1) Kecocokan keseluruhan model (overal model fit) adalah tahap pertama dari uji kecocokan ini ditujukan untuk mengevaluasi secara umum derajat kecocokan (Goodness of Fit Index) dengan kriteria: $P$-value $\geq 0,05=$ model fit, RMSEA $\leq$ $0,08=$ model fit, dan GFI, AGFI,CFI, NFI dan NNFI $\geq 0,09=$ model fit; 2) Analisis Kecocokan Model Pengukuran adalah evaluasi model pengukuran melalui dua tahapan yaitu: a) indikator dikatakan valid jika memiliki bobot faktor lebih besar dari 0,40, dan jika nilai t factor loading lebih besar dari nilai kritis $(\geq 1,96)$, dan standardized factor loadings $\geq 0,50$, dan b) reliabilitas yang baik jika nilai construct reliability $(\mathrm{CR}) \geq 0,70$, dan nilai variance extarcted (VE) $\geq 0,50$; dan 3) Analisis Keocokan Model Struktural (Structural Model Fit) yaitu analisis yang mencakup pemeriksaan terhadap signifikansi koefisien-koefisien yang diestimasi dengan menspesifikasi tingkat signifikansi pada alfa $(\alpha)$ sebesar 0,05 (5\%) pada angka mutlak 1,96. Selain itu, melihat nilai koefisien determinasi $\left(\mathrm{R}^{2}\right)$ persamaan struktural dimana, jika nilai $\mathrm{R}^{2}$ semakin tinggi maka semakin besar nilai-nilai independen (eksogen) dapat menjelaskan variabel endogen.

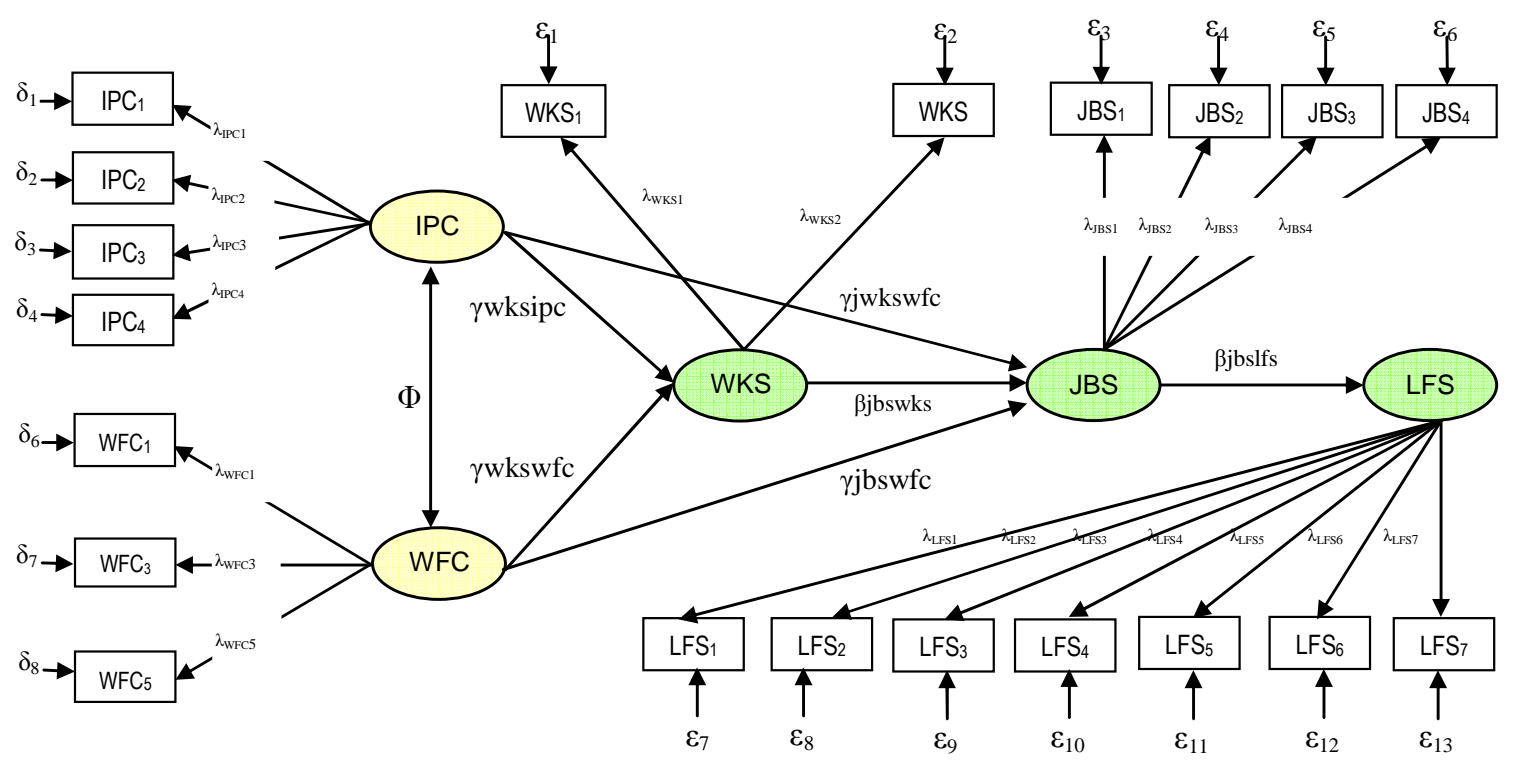

Gambar 1: Hybrid Model Pengaruh Langsung Antara Variabel Eksogen Dan Variabel Endogen 


\section{HASIL PENELITIAN DAN PEMBAHASAN Uji Normalitas Data (Test of Normality)}

Tabel 2: Uji Normalitas Data Multivariate

\begin{tabular}{lcccccccc}
\hline & Skewness & & \multicolumn{3}{c}{ Kurtosis } & \multicolumn{3}{c}{ Skewness \& Kurtosis } \\
$\underline{\text { Value }}$ & $\underline{\text { Z-Score }}$ & $\underline{\text { P-Value }}$ & $\underline{\text { Value }}$ & $\underline{\text { Z-Score }}$ & $\underline{\text { P-Value }}$ & $\underline{\text { Chi-Square }}$ & $\underline{\text { P-Value }}$ \\
61.446 & 8.314 & 0.000 & 459.141 & 4.580 & 0.000 & 90.097 & 0.000 \\
\hline
\end{tabular}

Hasil uji normalitas secara keseluruhan (multivariate) dapat dilihat pada tabel 2 . Berdasarkan tabel tersebut diperoleh nilai chi-square sebesar 90,097 dengan p-value sebesar 0,000 pada skewness and kurtosis yang berarti bahwa data variabel manifes tidak berdistribusi normal multivariat. Karena itu, menurut Raykov dan Marcoulides (2006), jika distribusi variabel observasi tidak normal dalam suatu penelitian, maka menggunakan metode Satorra-Bentler Robust Maximum Likelihood pada estimasi parameter. Metode estimasi ini pada program lisrel 8.80 digunakan dengan memasukan asymtotic covariance matrix, sehingga model akan diestimasi dalam keadaan data yang tidak normal.

\section{Kecocokan Keseluruhan Model}

Berdasar pengujian SEM dengan menggunakan metode estimasi Satorra-Bentler Robust Maximum Likelihood pada program LISREL 8.80, maka hasil uji kecocokoan keseluruhan model (goodness of fit) sebagaimana dapat dilihat pada tabel 3. Berdasarkan pada tersebut, ditunjukan kecocokan model secara keseluruhan (overall) menggunakan uji Satora-Bentler Scaled Probabilitas Chi-square $(X)^{2}$ diperoleh nilai sebesar 66,828 dengan $p$-value $=$ $0,175>0,05$. Berdasarkan hasil uji $\chi^{2}$ maka data empiris tidak edintik dengan teori/model atau model tidak fit. Namun demikian, menurut Bentler and Bonett diutip oleh Ghozali dan Fuad (2008) bahwa $\chi^{2}$ prosedur untuk menilai model fit hanya dengan $\chi^{2}$ (probilitasnya) ini kurang dapat dibenarkan. Dengan demikian diperlukan indikator-indikator lainnya untuk menilai fitnya model.

Selanjutnya hasil uji RMSEA= $0,04<0,08$ yang berarti good fit. Sedangkan hasil uji GFI $=0,90 \geq 0,90$, yang berarti bahwa model memiliki kecocokan yang baik (good fit). Selanjutnya, nilai $\mathrm{CFI}=0,99$, NFI $=0,97$, NNFI $=0,99$, IFI $=0,99$, dan RFI=0,97 lebih besar dari 0,90 yang berarti bahwa model memiliki kecocokan yang baik (good fit). Selain itu hasil ECVI memiliki nilai yang lebih kecil dari $3 \quad(E C V I=2,11<3)$ yang berarti bahwa, model juga memiliki kecocokan yang baik.

\section{Analisis Kecocokan Model Pengukuran (CFA)}

Confirmatory factor analysis-CFA digunakan untuk menguji validitas dan reliabilitas masingmasing indikator yang membentuk variabel laten. Berdasarkan metode estimasi SatorraBentler robust maximum likelihood diperoleh Hasil uji CFA dapat lihat pada tabel 4.

Tabel 3: Hasil Uji kecocokan Model

\begin{tabular}{clccc}
\hline No. & \multicolumn{1}{c}{ Indeks } & Hasil & $\begin{array}{c}\text { Nilai yang } \\
\text { Direkomen- } \\
\text { dasikan }\end{array}$ & $\begin{array}{c}\text { Kesim- } \\
\text { pulan }\end{array}$ \\
\hline 1 & S-BR Probabilitas Chi-square $(X)^{2}$ & 0,000 & $>0,05$ & No fit \\
2 & RMSEA & 0,04 & $\leq 0,08$ & Goodfit \\
3 & GFI & 0,90 & $\geq 0,90$ & Goodfit \\
4 & CFI, NFI, NNFI, IFI, RFI & $0,99,0,97,0,99,0,99,0,97$ & $>0,90$ & Goodfit \\
5 & ECVI & 2,11 & $<3$ & Goodfit \\
\hline
\end{tabular}




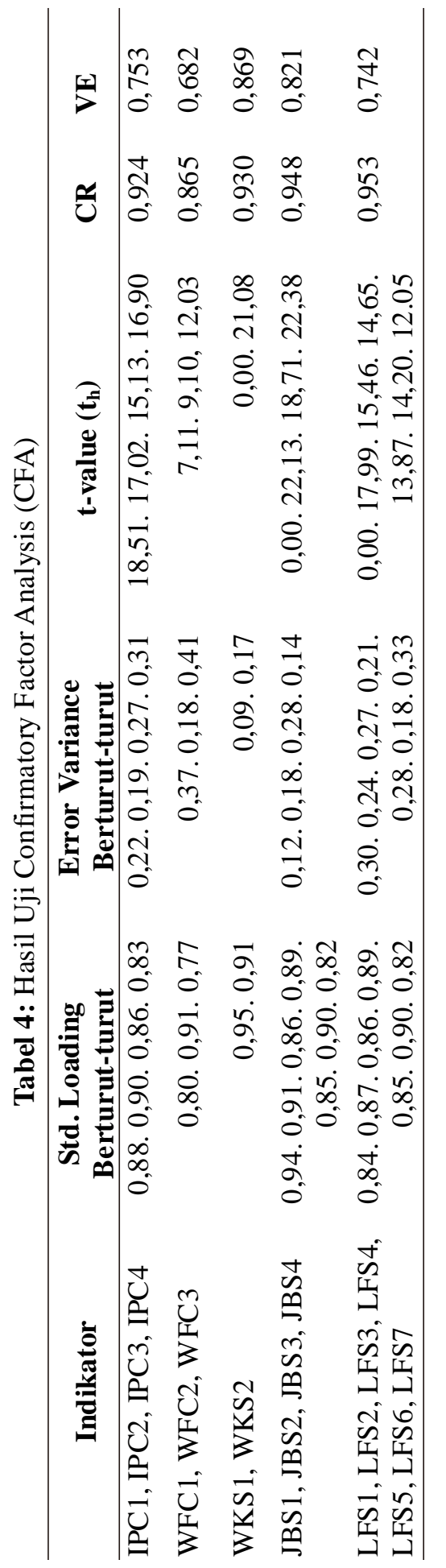

Berdasarkan Tabel 4 di atas meunjukan bahwa: 1) empat variabel manifes Konflik interpersonal (IPC) memiliki loading factors standardized solution lebih besar dari 0,40., dan nilai $t_{\text {hitung }}$ lebih besar dari $t_{\text {tabel }}=1,96$ yang berarti bahwa secara keseluruhan indikator tersebut memiliki tingkat validitas yang baik dalam mengukur variabel laten (Konflik interpersonal). Selain itu, nilai construct reliability (CR) Konflik Interpersonal sebesar 0,924 lebih besar dari 0,70 (CR>0,70) dan nilai average variance extracted (VE) sebesar 0,753 lebih besar dari 0,50 (VE>0,50) yang berarti indikator tersebut memiliki reliabilitas yang baik atau konsisten dalam mengukur variabel laten IPC; 2) tiga variabel manifes Work Family Conflict memiliki loading factors standardized solution lebih besar dari 0,40., dan nilai $\mathrm{t}_{\text {hitung }}$ lebih besar dari $\mathrm{t}_{\text {tabel }}=1,96$ yang berarti bahwa secara keseluruhan indikator tersebut memiliki tingkat validitas yang baik. Selanjutnya adalah nilai construct reliability (CR) Work-Familiy Cinflict sebesar 0,865 lebih besar dari 0,70 (CR>0,70) dan nilai average variance extracted (VE) sebesar 0,682 lebih besar dari 0,50 (VE>0,50), menunjukan bahwa indikator tersebut memiliki reliabilitas yang baik; 3) variabel manifes Stres Kerja memiliki loading factors standardized lebih besar dari 0,40 , dan nilai $t_{\text {hitung }}$ masing-lebih besar dari $t_{\text {tabel }}$ =1,96 yang berarti bahwa secara keseluruhan indikator tersebut memiliki tingkat validitas yang baik. Selain itu, nilai construct reliability (CR) Work-Familiy Cinflict sebesar 0,930 lebih besar dari $0,70(\mathrm{CR}>0,70)$ dan nilai average variance extracted (VE) sebesar 0,869 lebih besar dari 0,50 (VE>0,50), menunjukan bahwa indikator tersebut memiliki reliabilitas yang baik; 4) variabel manifes Kepuasan Kerja memiliki loading factors standardized lebih besar dari 0,40, dan nilai $t_{\text {hitung }}$ masing-lebih besar dari $t_{\text {tabel }}=1,96$ yang berarti bahwa secara keseluruhan indikator tersebut memiliki tingkat validitas yang baik. Selain itu, nilai construct reliability (CR) Work-Familiy Cinflict sebesar 0,948 lebih besar dari $0,70(\mathrm{CR}>0,70)$ dan nilai average variance extracted (VE) sebesar 0,821 lebih besar dari 0,50 (VE>0,50), menunjukan bahwa indikator tersebut memiliki reliabilitas yang baik; dan, 4) variabel manifes Kepuasan Hidup memiliki loading factors standardized lebih besar dari 0,40 , dan nilai $t_{\text {hitung }}$ masinglebih besar dari $t_{\text {tabel }}=1,96$ yang berarti bahwa secara keseluruhan indikator tersebut memiliki tingkat validitas yang baik. Nilai construct reliability (CR) Work-Familiy Cinflict sebesar 0,953 lebih besar dari $0,70(\mathrm{CR}>0,70)$ dan nilai average variance extracted (VE) sebesar 0,742 lebih besar dari 0,50 (VE>0,50), menunjukan bahwa indikator tersebut memiliki reliabilitas yang baik. 


\section{Analisis Keocokan Model Struktural}

Hasil analisis SEM dengan Lisrel menghasilkan 3 persamaan sub struktur yaitu: sub struktur pertama adalah WKS $=0.542 * \mathrm{IPC}+$ $0.306 *$ WFC, Errorvar. $=0.488, R^{2}=0.523$, sub struktur kedua adalah JBS $=-0.216^{*}$ IPC $0.531 *$ WKS $-0.160 *$ WFC, Errorvar.= 0.359, $\mathrm{R}^{2}=0.640$, dan sub struktur ketiga adalah LFS $=0.822 * \mathrm{JBS}$, Errorvar. $=0.328, \mathrm{R}^{2}=0.673$. Merujuk pada model sub struktur pertama, menunjukan bahwa: (1) besarnya pengaruh langsung konflik interpersonal dan work family conflict terhadap stres kerja (work stress) masing sebesar 0,542 dan 0,306, sedangkan secara simultan adalah sebesar $\mathrm{R}^{2}=0.523$ $(52,30 \%)$, dan sisanya sebesar Errorvar. $=0.488$ $(48,80 \%)$ merupakan pengaruh faktor-faktor lain yang tidak dijelaskan dalam penelitian ini; (2) model sub struktur kedua menunjukan pengaruh konflik interpersonal, work family conflict dan stres kerja terhadap pencegahan kepuasan kerja secara berturut-turut adalah $0,216,-0,531$, dan $-0,160$, sedangkan secara simultan adalah sebesar, $\mathrm{R}^{2}=0.640(64,00 \%)$, dan sisanya sebesar Errorvar. $=0.359(39,90 \%)$ merupakan pengaruh faktor-faktor lain yang tidak dijelaskan dalam penelitian ini; dan (3) model sub struktur ketiga menunjukan stres kerja terhadap pencegahan kepuasan hidup (life satisfaction) adalah 0,822 , sedangkan secara simultan adalah sebesar $\mathrm{R}^{2}=0,673(67,30 \%)$, dan sisanya sebesar Errorvar.= 0,328 (32,80\%) merupakan pengaruh faktor-faktor lain yang tidak dijelaskan dalam penelitian ini. Selain itu, IPC memiliki pengaruh langsung positif yang lebh besar dari WFC terhadap stres kerja, sedangkan pengaruh langsung negatif terhadap kepuasan kerja, variabel WKS lebih besar pengaruhnya dari pada IPC dan WFC.

Pengaruh variabel eksogen terhadap variabel endogen dalam bentuk hybrid model diagram jalur standardized solution dapat dilihat pada gambar 2 .

Merujuk pada gambar tersebut, dapat dijelaskan bahwa pengaruh tidak langsung (indirrect effects) IPC terhadap JBS melalui WKS adalah sebesar $0,541 \times(-0,531)=-0,288$, dan total pengaruh (total effects) adalah sebesar $(-0,288)+(-0,216)=-0,504$. Sedangkan pengaruh tidak langsung WFC terhadap JBS melalui WKS adalah sebesar $(0,306)$ x ($0,531)=-0,162$, dan total pengaruh (total effects) adalah sebesar $(-0,162)+(-0,160)=-$ 0,322 .

\section{Pengujian Hipotesis}

Berdasarkan perhitungan koefisien jalur dengan menggunakan Program LISREL 8.80, maka diperoleh nilai-nilai koefisien jalur masing variabel eksogen dan variabel endogen sebagaimana disajikan pada tabel 5 .

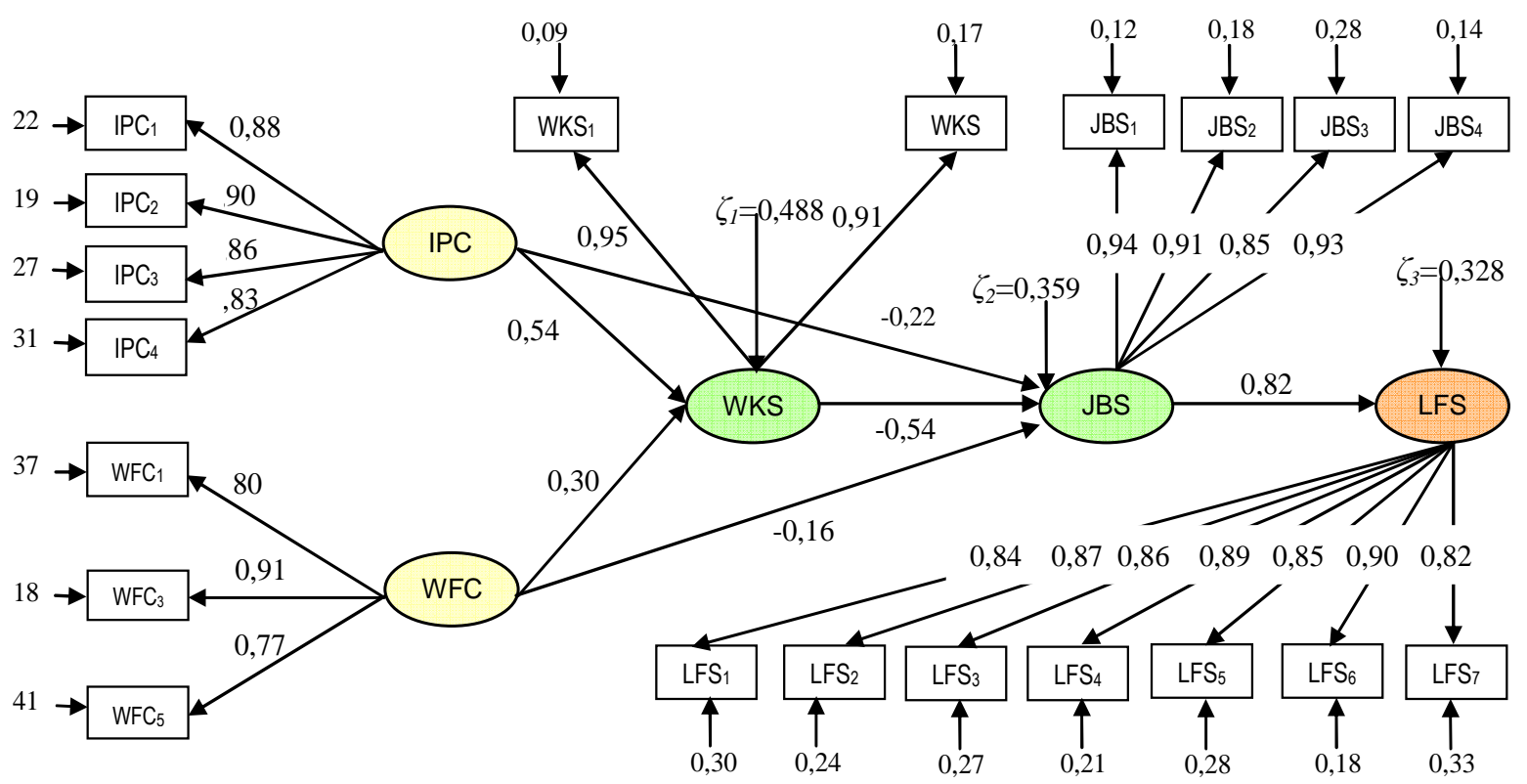

Gambar 2: Hybrid Model Diagram Jalur Standardized Solution 
Tabel 5: Rangkuman Hasil Pengujian Pengaruh Langsung Positif Variabel Eksogen dan Endogen

\begin{tabular}{cccccc}
\hline Sampel & Koefisien Jalur & Nilai Koefisien & $\mathbf{t}_{\text {hitung }}$ & $\mathbf{t}_{\text {tabel }(\boldsymbol{a}=\mathbf{0}, \mathbf{0 5})}$ & Kesimpulan \\
\hline 200 & $\gamma$ wksipc & 0,54 & 5,54 & 1,96 & Signifikan \\
200 & $\gamma$ wkswfc & 0,30 & 2,86 & 1,96 & Signifikan \\
200 & $\gamma$ jbsipc & $-0,22$ & $-2,74$ & 1,96 & Signifikan \\
200 & $\gamma j b s w f c$ & $-0,16$ & $-3,05$ & 1,96 & Signifikan \\
200 & $\gamma$ jbswks & $-0,54$ & $-6,96$ & 1,96 & Signifikan \\
200 & $\gamma$ lfsjbs & 0,82 & 13,72 & 1,96 & Signifikan \\
\hline
\end{tabular}

Berdasarkan pada tabel 5 di atas menunjukan, Pertama: Koefisien jalur pengaruh langsung positif konflik interpersonal terhadap stres kerja $(\gamma w k s i p c)=(0,54)^{2} \times 100 \%$ $=29,16 \%$ dan nilai $\mathrm{t}_{\text {hitung }}=5,54$ lebih besar dari nilai $\mathrm{t}_{\text {tabel }(\alpha=0,05)}=1,96$. Hasil ini menunjukan bahwa semakin tinggi konflik interpersonal (IPC) yang dialami pegawai maka kecenderungannya semakin tinggi tingkat stres kerja (WKS) pegawai. Dengan kata lain, terdapat pengaruh langsung positif konflik interpersonal terhadap stres kerja Pegawai Negeri Sipil di Sekretariat Jenderal Kementerian Pendidikan dan Kebudayaan. Temuan ini relevan dengan teori dari McShane dan Glinow (2008) bahwa konflik kerja akibat dari hubungan antar pribadi dapat meningkatkan stres kerja seseorang atau seorang karyawan akan mengalami stres negatif (distress) yang bersumber dari hubungan antarpersonal (interpersonal stressors). Selain itu, hasil penelitian ini juga relevan dengan hasil penelitian yang dilakukan oleh Judge and Collquit (2004), Hershcovis and Barling (2007), Ahsan, et al. (2009), dan Ito and Brotheridge (2009) bahwa konflik antar pribadi (interpersonal conflict) berpengaruh positif terhadap stres kerja (work stress). Mendukung temuan-temuan ini, hasil penelitian Ullah (2012) menjelaskan bahwa konflik interpersonal dan stres kerja berhubungan satu sama laindan terdapat hubungan yang positif antara konflik interpersonal dan stres kerja.

Kedua: Koefisien jalur pengaruh langsung positif work family conflict terhadap stres kerja $(\gamma w k s w f c)=(0,30)^{2} \times 100 \%=9,00 \%$ dan nilai $t_{\text {hitung }}=2,86$ lebih besar dari nilai $t_{\text {tabel }}$ $(\alpha=0,05)=1,96$. Hasil ini menunjukan bahwa semakin tinggi work family conflict (WKS) yang dialami pegawai maka kecenderungannya semakin tinggi tingkat stres kerja (WKS) pegawai. Dengan kata lain, terdapat pengaruh langsung positif konflik keluarga sebagai akibat dari interfensi pekerjaan (work- family conflict) terhadap stres kerja Pegawai Negeri Sipil di Sekretariat Jenderal Kementerian Pendidikan dan Kebudayaan.

Temuan ini relevan dengan pendapat Frone, et al. Dikutip oleh Huffman (2004) bahwa pekerjaan dapat mengganggu keluarga dan keluarga dapat mengganggu pekerjaan. Gangguan antara kedua domain (pekerjaan dan keluarga) secara alami saling mempengaruhi. Hal ini mengambarkan bahwa tuntutan pekerjaan dapat mengganggu keluarga dan sebaliknya tuntutan keluarga dapat mengganggu pekerjaan. Dengan demikian pegawai negeri sipil yang berada dalam situasi tersebut dapat berpengaruh terhadap baik/buruknya fisik dan psikisnya. Dengan kata lain, respon seorang pegawai terhadap apapun akan mempengaruhi tingkat stres secara fisiologi dan psikologi, sebagaimana dikemukakan oleh McShane dan Glinow (2008) bahwa stres merupakan respon adaptif terhadap situasi yang dirasakan sebagai tantangan atau ancaman terhadap kesehatan seseorang. Lebih lanjut dijelaskan bahwa salah satu sumber stres kerja adalah hal-hal yang tidak berkaitan dengan pekerjaan yang diistilahkan dengan nonwork stressors yakni, stres yang berkaitan dengan keseimbangan antara waktu kerja dan waktu di luar kerja.

Selain hal di atas, penelitian ini juga relevan dengan hasil penelitian yang dilakukan oleh Judge and Colguitt (2004), Hammer, et al. (2004), Mckee (2007), Bazana and Dodd (2013), dan Ito and Brotheridge (2009) yang menunjukan work-family conflict berpengaruh positif terhadap stres kerja.

Berdasarkan uraian di atas, jelas bahwa setiap orang/pegawai pasti mengalami stres, 
baik di luar organisasi maupun di dalam organisasi apapun. Dengan kata lain, setiap orang tidak dapat menghindari stres, untuk itu pegawai negeri sipil dan pimpinan di Sekretariat Jenderal Kementerian Pendidikan dan Kebudayaan diberbagai level perlu untuk mengelola stres dengan baik. Karena, ketika seorang pegawai maupun pimpinan mampu mengelola stresnya dengan baik, maka konsekuensinya adalah fungsional (positif), sebaliknya jika mengabaikan stres yang muncul, konsekuensinya adalah disfungsional (negatif) terhadap individu maupun organisasi. Jadi, stres tidak hanya berdampak negatif, tetapi juga berdampak positif pada seseorang. Hal tersebut sesuai dengan pendapat yang dikemukakan oleh Pioner Stres: Selye dikutip oleh Kreitner dan Kinicki (2005), dan Luthan (2008) bahwa stres bukanlan sekedar ketegangan syaraf (distress), stres dapat memiliki konsekuensi yang positif (eustress), stres bukanlah sesuatu yang harus dihindari, dan tidak adanya stres sama sekali adalah kematian.

Ketiga: Koefisien jalur pengaruh langsung negatif konflik interpersonal terhadap kepuasan kerja $(\gamma \mathrm{jbsipc})=(-0,22)^{2} \times 100 \%$ $=4,48 \%$ dan nilai $\mathrm{t}_{\text {hitung }}=-2,74$ lebih besar dari nilai $\mathrm{t}_{\text {tabel }(\alpha=0,05)}=-1,96$. Hasil memberi arti bahwa semakin tinggi konflik interpersonal (IPC) yang dialami pegawai maka kecenderungannya semakin rendahya tingkat kepuasan kerja (JBS) pegawai. Dengan kata lain, terdapat pengaruh langsung negatif konflik interpersonal terhadap kepuasan kerja Pegawai Negeri Sipil di Sekretariat Jenderal Kementerian Pendidikan dan Kebudayaan. Dengan demikian, konflik antar sesama pegawai maupun anatar pegawai dengan atasan langsungnya (pimpinan) dapat menyebabkan kietidak kepuasan kerja kerja (dissatifaction) pegawai. Sejalan dengan ini, Kreitner dan Kinicki (2005) mengemukakan bahwa konflik kepribadian merupakan pertentangan antar pribadi yang didorong oleh ketidaksukaan atau ketidaksepakatan yang sifatnya pribadi. Konflik kepribadian yang kronis dimulai dengan kemarahan yang tampaknya tidak signifikan. Jika demikian, maka seorang pegawai yang mengalami konflik dengan pegawai lain akan menurunkan semangat kerjanya dan pada akhirnya menurunkan tingkat kepuasan di tempat kerja. Hal ini bertentangan dengan teori kepuasan kerja sebagaimana dikemukakan oleh oleh Daft (2006) bahwa kepuasan kerja adalah sebuah sikap positif terhadap pekerjaan seseorang. Robbins dan Judge (2008) juga menjelasakan bahwa kepuaan kerja merupakan suatu perasaan positif tentang pekerjaan seseorang yang merupakan hasil dari sebuah evaluasi karakteristiknya. Namun demikian kepuasan kerja tidak hanya membicarakan tentang hal yang menyenangkan (sikap positif), tetapi juga secara implisit berkaitan dengan ketidakpuasan kerja (sikap negatif) seorang individu di tempat kerjanya. Konflik interpersonal merupakan salah satu sumber yang menyebabkan seorang pegawai merasakan ketidakpuasan kerja terhadap pekerjaanya. Sejalan dengan ini, menurut Ho, et al. (2009) bahwa kepuasan kerja adalah sikap positif atau negatif yang dimiliki seorang karyawan tentang pekerjaannya atau beberapa aspek spesifik pekerjaan, dan merupakan pandangan internal seorang individu. Karena itu, konflik interpersonal perlu untuk dikelola sehingga konflik dapat berdampak positif (konstruktif). Senada dengan pernyataan ini Newstrom (2002) juga mengatakan bahwa konflik dapat berdampak positif dan negatif. Dampak positif dari konflik adalah (1) Orangorang dalam suatu organisasi didorong untuk mencari pemecahan masalah dan melakukan pendekatan-pendekatan yang terbaik sehingga akan meningkatkan kreativitas dan banyak mencoba hal-hal baru; dan (2) Dapat menanggulangi masalah-masalah yang terpendam namun sangat perlu untuk diselesaikan, maka konflik di masa yang akan datang dapat dihindarkan.

Hasil penelitian ini juga relavan dengan penelitian terdahulu yaitu penelitian yang dilakukan oleh Bradford, et al. (2001),Dreu (2003), Medina, et al. (2005) Khan, et al. (2009) yang menunjukan bahwa konflik antar pribadi (konflik tugas dan konflik hubungan) berpengaruh negatif terhadap kepuasan kerja karyawan.

Keempat: Koefisien jalur pengaruh langsung negatif work family conflict terhadap kepuasan kerja $(\gamma \mathrm{jbswfc})=(-0,16)^{2} \times 100 \%$ $=2,56 \%$ dan nilai $\mathrm{t}_{\text {hitung }}=-3,05$ lebih besar dari nilai $\mathrm{t}_{\text {tabel }(\alpha=0,05)}=-1,96$. Hasil ini menunjukan 
bahwa semakin tinggi work family conflict (WFC) yang dialami pegawai maka kecenderungannya semakin rendahya tingkat kepuasan kerja (JBS) pegawai. Dengan kata lain, terdapat pengaruh langsung negatif work family conflict terhadap kepuasan kerja Pegawai Negeri Sipil di Sekretariat Jenderal Kementerian Pendidikan dan Kebudayaan. Temuan ini relevan dengan teori Mathis, et al. (2007) bahwa konflik keluarga (work-family conflict) akibat dari intervensi pekerjaan (work interference family) berpengaruh negatif terhadap kepuasan kerja. Artinya, konflik yang dialami seorang pegawai di lingkungan keluarga (misalnya: masalah keuangan, kesehatan anak, perumahan, dan lain-lain) akan berdampak negatif terhadap pekerjaannya termasuk didalamnya adalah perasaan tidak puas terhadap pekerjaan.

Hasil penelitian ini juga relevan dengan hasil penelitian terdahulu yang dilakukan oleh Judge \& Colquitt (2004); Grandey, et al. (2005), Janazs \& Behson (2007), Mathis, et al. (2007), dan Bhowon (2013) yang menunjukan bahwa work-family conflict berpengaruh negatif terhadap kepuasan kerja (job satisfaction).

Menurut Salguero (2010) dalam penelitiannya menyimpulkan bahwa para organisasi harus mengetahui bagaimana workfamily conflict mempengaruhi sikap kerja karyawan dari budaya yang berbeda, sebagai kebijakan yang telah dilaksanakan untuk mengurangi stres kerja sehingga mampu meningkatkan kepuasan kerja. Hasil penelitiannya adalah work family conflict berpengaruh terhadap kepuasan kerja.

Kelima: Koefisien jalur pengaruh langsung negatif stres kerja terhadap kepuasan kerja $(\gamma \mathrm{jbswks})=(-0,54)^{2} \times 100 \%=29,16 \%$ dan nilai $\mathrm{t}_{\text {hitung }}=-6,96$ lebih besar dari nilai $\mathrm{t}_{\text {tabel }(\alpha=0,05)}=-$ 1,96. Hasil ini menunjukan bahwa semakin tinggi stres kerja (WKS) yang dialami pegawai maka kecenderungannya semakin rendahya tingkat kepuasan kerja (JBS) pegawai. Dengan kata lain, terdapat pengaruh langsung negatif stres kerja (WKS) terhadap kepuasan kerja Pegawai Negeri Sipil di Sekretariat Jenderal Kementerian Pendidikan dan Kebudayaan. Temuan ini relevan dengan teori Stres yang dikemukakan oleh Mcshane dan Glinow (2008) penyebab stres karena adanya interaksi antar staf atau antara staf dan supervisi (interpersonal stressors) dapat menyebabkan ketidakpuasan kerja. Lebih lanjut dijelaskan bahwa kemungkinan konsekuensi dari stres adalah negatif (distress) di antaranya adalah menimbulkan kelelahan emosional dan ketidakpuasan kerja (dissatisfaction). Karena itu stres perlu dikelola oleh manajemen untuk meningkatkan kepuasan kerja. Menurut Robbins dan Judge (2008) pengelolaan stres kerja dilakukan dengan dua pendekatan yaitu: 1) Pendekatan Individual. Karyawan dapat memikul tanggung jawab pribadi untuk mengurangi tingkat stresnya. Strategi individu yang telah terbukti efektif mencakup pelaksanaan teknik teknik manajemen waktu, meningkatkan latihan fisik, pelatihan pengenduran (relaksasi), dan perluasan jaringan dukungan sosial; dan 2) Pendekatan organisasi. Beberapa faktor yang menyebabkan stres terutama tuntutan tugas dan peran dan struktur organisasi dikendalikan oleh manajemen. Dengan demikian faktor-faktor ini dapat dimodifikasi atau diubah. Strategi yang mungkin perlu dipertimbangkan oleh pihak manajemen adalah perbaikan seleksi personil, penempatan, penetapan sasaran yang realistis, perancangan ulang pekerjaan, peningkatan keterlibatan karyawan, perbaikan komunikasi organisasi, dan penegakan program kesejahteraan perusahaan.

Selain hal di atas, penelitian ini juga relevan dengan hasil penelitian terdahulu yang dilakukan oleh Arasly andTumer (2008), Franzcp, et al. (2008), Karadal, et al. (2008), Ito and Brotheridge (2009), dan Ahsan, et al. (2009) yang menemukan bahwa, stres kerja (work stress) berpengaruh negatif terhadap kepuasan kerja (job satisfaction). Mendukung temuan ini, hasil penelitian Mansoor, et al. (2011) menemukan bahwa stres kerja yang terdiri dari: beban kerja, konflik peran, dan lingkungan fisik berpengaruh negatif terhadap kepuasan kerja karyawan.

Keenam: Koefisien jalur pengaruh langsung positif kepuasan kerja terhadap kepuasan hidup $(\gamma \mathrm{jbswks})=(0,82)^{2} \times 100 \%$ $=67,24 \%$ dan nilai $t_{\text {hitung }}=13,72$ lebih besar dari nilai $\mathrm{t}_{\text {tabel }(\alpha=0,05)}=1,96$. Hasil ini menunjukan bahwa semakin tinggi tingkat kepuasan kerja (JBS) yang dialami pegawai maka kecenderungannya semakin tinggi tingkat 
kepuasan hidup (LFS) pegawai. Dengan kata lain, terdapat pengaruh langsung positif kepuasan kerja terhadap kepuasan hidup Pegawai Negeri Sipil di Sekretariat Jenderal Kementerian Pendidikan dan Kebudayaan. Temuan ini relevan teori yang dikemukakan oleh Justina (2011) bahwa kepuasan juga dapat dinilai sehubungan dengan aspek-aspek tertentu dari kehidupan seseorang, atau domain tertentu, sebagai contoh kepuasan finansial (kepuasan dengan kekayaan seseorang dan situasi pendapatan), kepuasan kerja, dan kepuasan dengan kesehatan seseorang. Ini berarti, kepuasan hidup juga bersumber dari kepuasan kerja misalnya pendapatan (gaji/upah) yang dapat memotivasi karyawan untuk bekerja lebih baik. Kepuasan hidup juga merupakan evaluasi tehadap kehidupan secara keseluruhan diantaranya bersumber dari pekerjaan dan keluarga (Arslan dan Acar, 2013)

Temuan dalam penelitian ini konsistem dengan Hasil penelitian terdahulu yang dilakukan oeh Lian et al. (2007), Senter (2010), dan Ghazzawi (2008) menunjukan bahwa kepuasan kerja berpengaruh positif terhadap kepuasan hidup (life satisfaction). Selain itu, hasil penelitian Arslan dan Acar (2013) menjelaskan bahwa masalah keluarga memberikan kepuasan kerja bagi akademisi yang menghabiskan sebagian besar waktu mereka di perguruan tinggi memberikan kontribusi terhadap kepuasan hidup. Orangorang yang senang di tempat kerja akan dikenal di masyarakat sebagai sangat toleran, perhatian dan mendukung rekonsiliasi daripada fokus pada konflik. Hasil penelitiannya menunjukan bahwa kepuasan kerja berhubungan positif dengan laife satisfaction. Lebih lanjut dalam penelitiannya menjelaskan bahwa para akademisi dengan tingkat kepuasan hidup yang tinggi juga memiliki kepuasan kerja yang tinggi. Selain itu, perasaan negatif seperti kelelahan emosional (emotional exhoustion), depersonalisasi (depersonalization), kegagalan pribadi (personal failure) dan kelelahan (burnout) cenderung menurun dengan adanya peningkatan pada life satisfaction dan job satisfaction. Kepuasan hidup dan kepuasan kerja akademisi yang dapat memperoleh baik melalui lingkungan kerja atau melalui komunikasi interpersonal memiliki kepentingan yang signifikan memperoleh sukses secara komprehensif.

\section{PENUTUP \\ Kesimpulan, Implikasi dan Keterbatasan Penelitian}

Penelitian ini telah membuktikan hipotesishipotesis yang diajukan, dan juga konsisten dengan penelitian-penelitian terdahulu. Pengujian H1 menunjukan bahwa terdapat pengaruh langsung positif konflik interpersonal terhadap stres kerja Pegawai Negeri Sipil, H2 menunjukan terdapat pengaruh langsung positif konflik keluarga sebagai akibat dari interfensi pekerjaan (work- family conflict) terhadap stres kerja Pegawai Negeri Sipil, H3 terdapat pengaruh langsung negatif konflik interpersonal terhadap kepuasan kerja, H4 terdapat pengaruh langsung negatif work family conflict terhadap kepuasan kerja Pegawai Negeri Sipil, H5 terdapat pengaruh langsung negatif stres kerja (WKS) terhadap kepuasan kerja Pegawai Negeri Sipil, dan H6 terdapat pengaruh langsung positif kepuasan kerja terhadap kepuasan hidup Pegawai Negeri Sipil di Sekretariat Jenderal Kementerian Pendidikan dan Kebudayaan. Secara keseluruhan hasilhasil penelitian ini konsistend dengan temuantemuan terdahulu.

Berdasarkan uraian di atas, maka implikasinya adalah bahwa Sekretariat Jenderal Kementerian Pendidikan dan Kebudayaan ada baiknya mengelola konflik interpersonal dan konflik keluarga yang sedang dialami oleh pegawai, dengan cara melakukan identifikasi secara akurat dan mengevaluasinya melalui pendekatan-pendekatan yaitu: Collaborating adalah mencoba menemukan penyelesaian yang menguntungkan kedua belah pihak yang terlibat konflik melalui problem solving. Hal yang terpenting dari gaya collaborating ini adalah orang-orang yang terlibat saling berbagi informasi untuk mengidentifikasi potensi solusi yang dapat membuat kedua pihak merasa puas. Avoiding adalah mencoba untuk menghindari situasi konflik. Misalnya beberapa karyawan akan mengatur kembali tempat kerja atau tugasnya untuk meminimalkan interaksi dengan co-workers. Competing adalah mencoba untuk memenangkan konflik. Gaya ini lebih mengarah pada orientasi win-lose karena 
berada pada tingkat assertive yang tinggi dan cooperative yang rendah. Accomodating adalah gaya yang manajemen konflik yang mempertimbangkan kedua pihak yang terlibat. Jadi tidak mementingkan kepentingan diri sendiri. Compromising adalah mencoba untuk mencari jalan tengah, di mana setiap pihak memiliki sesuatu yang ditawarkan dan diterima. Sedangkan pengelolaan stres kerja pegawai dapat dilakukan dengan dua pendekatan yaitu: 1) Pendekatan Individual. Karyawan dapat memikul tanggung jawab pribadi untuk mengurangi tingkat stresnya, dan 2) Pendekatan organisasi. Beberapa faktor yang menyebabkan stres terutama tuntutan tugas dan peran dan struktur organisasi dikendalikan oleh manajemen. Manajemen konflik dan stres jika dilakukan dengan penuh rasa tanggungjawab dan konsisten, maka dapat mengurangi tingkat stres kerja dan meningkatkan kepuasan kerja pegawai negeri sipil yang pada akhir akan berdampak positif atau meningkatnya kepuasan kerja dan kepuasan hidup pegawai negeri sipil di lingkungan Sekretariat Jenderal Kementerian Pendidikan dan Kebudayaan.

Penelitian ini masih memiliki keterbatasan yaitu bahwa Instrumen pengumpulan data menggunakan kuesioner memungkinkan data yang diperoleh tidak dapat menggali informasi yang dibutuhkan secara menyeluruh dan mendalam. Selain itu, dalam penelitian ini, peneliti hanya membatasai 5 variabel yaitu, konflik interpersonal, dan work family conflict sebagai variabel eksogen, stres dan kepuasan kerja sebagai variabel eksogen dan juga diberlakukan sebagai variabel endogen (intervening), serta kepuasan hidup sebagai variabel ensogen. Sementara itu, secara teoretik, masih terdapat variabel lain yang mepengaruhi stres kerja, kepuasan kerja, dan kepuasan hidup namun tidak dianalisis dalam penelitian ini. Karena itu, penulis berharap kepada berbagai pihak yang berkepentingan dengan hasil riset ini dapat melakukan penelitian lanjutan dengan memasukan variabel-variabel lain yang tidak penulsi digunakan.

\section{DAFTAR PUSTAKA}

Ahsan, N., Z. Abdullah, DYG. Fie and SS. Alam. 2009. A Study of Job Satisfaction Among University Staff in
Malaysia: Empirical Study. European Journal of Social Science. 8(1). 121131.

Akehurst, G., JM. Comeche and MA. Galindo. 2009. Job Satisfaction and Commitment in the Entrepreneurial SME. To be Published Business Economic: An Enterpreneurship Journal. 2 (31). 1-18.

Arasli, H. and M. Tumer. 2008. Nepotism, Favoritm, and Cronysm: A Study of Their Effect on Job Stress and Job Satisfaction in The Banking Industry of North Cyprus. Social Behavior and Personality. Psychology Journal, Sociaety for Personality Research (Inc). 36(9). 1237-1250.

Arslan, R. and N. Acar. 2013. A research on academics on life Satisfaction, job satisfaction and Professional burnout. The Journal of Faculty of Economics and Administrative Sciences. 18 (6). 281-298.

Antonia Calvo-Salguero, AC., AM.C. González., J.Maria and SM.de Lecea. 2010. Relationship Between WorkFamily Conflict and Job Satisfaction: The Moderating Effect of Gender and the Salience of Family and Work Roles. African Journal of Business Management, 4 (7), 1247-1259.

Bazana, S. and N, Dodd. 2013. Conscientiousness, Work Family Conflict and Stress Amongst Police Officers in Alice, South Africa. Journal of Psycology. 4 (1). 1-8.

Bradford, DK., A. Stringfellow and BA. Weitz. 2001. Managing Conflict To Improve The Effectiveness of Ad-Hoc Marketing Teams. The International Journal of Conflict. 1-33.

Brillhart, PE. 2004. Technostress in The Workplace Managing Stress in The Electronic Workplace. Journal American Academy of Business. 5 (12). 302-307.

Brumels, K. and A. Beach. 2008. Professional role compelxity and job satisfaction of 
collegiate certified atletic trainers. Journal Athletic trainer, Academic research library. 43(4). 377-378.

Byron, K. (2005). A meta-analytic review of work-family conflict and its antecedents. Journal of Vocational Behavior. 67. 169-198.

Daft, RL. 2006. Management. Terjemahan oleh Diana Angelica, Salemba Empat, Jakarta.

Davis, Keith, and John, W. Newstroom, 2002. Organizational Behavior, Human Behaviour at Work, 11 th Edition, Mc Graw Hill/Irwin.

Dierdorff, EC. and JK. Ellington. 2008. It's the Nature of the Work: Examining Behavior-Based Sources of WorkFamily Conflict Across Occupations. Journal of Applied Psychology. 93(4). 883-892.

Dreu, C. KWD. 2003. Task Versus Relationship Conflict, Team Performance, and Team Member Satisfaction: A Mata-Analysis. Journal of applied Psychology. 88(4). 741-749.

, 2007. The Virtue and Vice of Workplace Conflict: Counterpoint Food For (Pessimistic) Thought. Journal of Organizational Behavior. 29. 5-18.

Fliege, H., M. Rose., MD. P. Arck., OB. Walter, RD. Kocalevent, C. Weber, and BF. Klapp. 2005. The Perceived Stress Questionnaire (PSQ) Reconsidered: Validation and Reference Value From Different Clinical and Health Adulth Samples. American Psychosomatic society. Journal of Psychosomatic Medicine. 67. 78-88.

Forgeard, MJC., E. Jayawickreme, ML., Kern and M.EP., Seligman. 2011. Doing the right thing: Measuring wellbeing for public policy. International journal of Wellbeing (IJW). 1(1). 79-106.

Franzcp, SK. 2008. Job Satisfaction Among Psychiatrists: An Urgent Area For
Research. Mental Health Journal, 13(3). 16-23.

George, J.M. \& GR. Jones. (2008). Understanding and managing Organizational Behavior (Fifth Edition). Upper Saddle River: New Jersey, Pearson Prentice Hall.

Ghazzawi, I. 2008. Job Satisfaction Antecedents and Consequences: A New Copceptual Framework and Research Agenda. The Business Review, Cambridge. 11(2). 1-11.

Gibson, L., JIM. John., DH. James and K. Robert. 2006. Organization Behavior, Structure and Process Twelfth Editions, Mc Graw Hill Irwin, Campanies, Inc. New York.

Grandey, AA., BL. Cordeiro and AC. Crouter. 2005. A Longitudinal and Multi-source Test of the Work-Family Conflict and Job Satisfaction Relationship. Journal of Occupational an d Organizational Psychology. 78. 1-20.

Greenhaus, J. H., TD., Allen and PE. Spector. 2006. Health consequences of workfamily conflict: The dark side of the work-family interface. In P. L. Perrewe \& D. C. Ganster (Eds.), Research in occupational stress and well-being. 5. 61-98).

Grzywacz, JG., TA., Arcury., A. Marin., L. Carrilo and B. Burke., ML. Coutes, and SA. Quandt. 2007. Work-Family Conflict: Experience and health Implication Among Immigrant Latinos. Journal of Applied Psychology, 92(4). 1119-1130.

Hair, Jr. J. F., et al. (2009). Multivariate Data Analysis, Sixth Edition. New Jersey: Pearson Prentice Hall Education International.

Hammer, TH., PO., Saksvik, K. Nytro., H. Torvatn and M. Bayazit. 2004. Expanding the Psychosocial Work Environment: Workplace Norms and Work-Family Conflict as Correlates of Stress and Health. Journal of 
Occupational Health Psychology, 9(1). 83-97.

Henry, O. 2009. Organizational Conflict and its Effects on Organizational Performance. Research Journal of Business Management, 2(1): 16-24.

Hershcovis, MS., N.Turner., J. Barling., KA. Arnold., KE. Dupre. M. Innes., ML., LeBlanc and N. Sivanathan. 2007. Predicting Workplace Aggression: A Meta - Analysis. Journal Of Aplied Psykology, 92(1). 228-238.

Ho, HW., CS. Chang, YL. Shih and RD. Liang. 2009. Effects of Job Rotation and Role Stress Among Nurses On Job Satisfaction and Organizational Commitment. BMC Health Services Research, BioMed Central Ltd. 9 (8). 1-10.

Huffman, AH. 2004. An Examination of the Perceived Direction of Work-Family Conflict. Dissertation, Doctor of Philosophy, Texas A \& M University. 1-141.

Ito, JK., Jack and CM. Brotheridge. 2009. Work-Family And Interpersonal Conflict As Mediators Of The Effects Of Demands/Resources On Emotional Exhaustion And Job Satisfaction: An Integrative Model. Journal of Vocational Behavior, (74), 1-16.

Ivancevich, JMR., Konopaske dan TM. Matteson. 2007. Organizational Behavior and Management Seventh Editions. Terjemahan Jilid 1 oleh Gina Gania, Gelora Aksara Pratama, Jakarta.

Janazs, SC. and SJ., Behson. 2007. Cognitive Capacity for Processing Work-Family Conflict: an Initial Examinations. Career Development International, 12(4). 397-411.

Janazs, SC., O. Dowd., Karen and ZB. Schneider. 2006. Interpersonal Skill in Organizations. Mc Graw Hill/Irwin.

Judge, TA. \& S. Watanabe. 1993. Another look at the jobsatisfaction-life satisfaction relationship. Journal of Applied Psychology, 78. 939-948.

Judge, TA. and JA. Colquitt. 2004. Organizational Justice and Stress: The Mediating Role of Work-Family Conflict. Journal of Applied Psychology, 89(3). 394-404.

Justina, AV. F. 2009. Subjective Well-Being as Welfare Measure: Concepts and Methodology, MPRA Paper No. 16619, posted 29. 1-43.

Karadal, H., U. Ay and MT., Cuhadar. 2008. The Effect of Role Conflict and Role ambiguity on Job Satisfaction and Organizational Commitment: A Study in the Public and Private Sector. The Journal of American Academy of Business, 13(2). 176-181.

Khan, MA., H. Afzal and KU. Rehma. 2009. Impact of Task Conflict Employee's Performance of Financial Institutions. European Journal of Scientific Research, 27(4). 479-487.

Kreitner, R. and A. Kinicki. 2005. Organizational Behavior $5^{\text {th: }}$ Terjemahan oleh Erly Suandy, Salemba Empat, Jakarta.

Kusnendi, 2008. Model-Model Persamaan Struktural. Satu dan Multigrup Sampel Dengan Lisrel. Bandung: Alfabeta.

Lian, JW., TM., Lin., and HK. Wu. 2007. Job Stres, Job Satisfaction And Life Satisfaction Between Managerial And Technical Is Personnel. Department of Information Management, National Central University, No.300, Jhongda Rd., Jhongli City, Taoyuan County 32001, Taiwan, R. O. C. 1-17.

Luthans, F. 2008. Organizational Behavior Eleventh Editions. Mc Graw Hill Irwin, Campanies, Inc. New York.

Mathis, CJ., Jackson and UJ. Brown. 2007. Work-family Conflict and Job Satisfaction: The Mediating Effects of Job-Focused Self-Efficacy. Allied Academy International Conference. 12(2). 5-8. 
Mathis, RL. and JH, Jackson. 2006. Human Resource Management, $10^{\text {th }}$ Edition. Terjemahan oleh Diana Angelica, Salemba Empat, Jakarta.

Mazaheri, M. 2010. Overal, and Specific Life Satisfaction Domain: Preliminary Iranian Students Norms, (Iranian J Public Health, 39(2). 89-94.

Mckee, JM. 2007. Work-Nonwork Conflict: A Self-Regulatory Expansion of Work Life Conflict. Dissertation. Doctor of Philosophy, Ohio State University. 1114.

McMillan, HS. 2011. Examining the Relationship between Work/Life Conflict and Life Satisfaction in Executives: The Role of ProblemFocused Coping Techniques. A Dissertation, Presented for the Doctor of Philosophy Degree, The University of Tennessee, Knoxville, 1-76.

McShane, SL. and MAV, Glinow. 2008. Organizational Behavior Fourt Edition. Mc Graw Hill Irwin, Campanies, Inc. New York.

Medina, FJ., L. Munduate., MA, Dorado., I. Martinez and JM, Guerra. 2005. Types of Intergroup Conflict and Affective Reactions. Journal of managerial Phsychology, 20(3). 219-230.

Mesmer, M.JR. and C, Viswesvaran. 2005. Convergence between measures of work-to-family and family-to-work conflict: Ameta-analytic examination. Journal of Vocational Behavior, 67. 15-232.

Mansoor, M., MA. Jinnah, S. Fida, S. Nasir and Z. Ahmad. 2011. The Impact of Job Stress on Employee Job Satisfaction A Study on Telecommunication Sector of Pakistan. Journal of Business Studies Quarterly. 2 (3). 50-56.

Muhammad Arif Ullah. 2012. Job stress as a result of interpersonal conflict. An Empirical evidence from the banking sector of Pakistan. Interdisciplinary
Journal Of Contemporary Research In Business 3 (9). 90 -95.

Pavot, W. and Ed. Diener. 1993. Review of The Satisfaction With Life Scale. American Psychological Association, Inc. 5(2). 164-172

Raeva, DL., NWH. Jansen., VD. PA. Brandt, RM.Vasse, and I. Kant. 2008. Risk Factors For Interpersonal Conflict At Work. Scandinavian Journal of Work, Environment and Health, 34(2). 96106.

Raykov, T., and Marcoulides, A. G. (2006). A First Course in Structural Equation Modeling, Second Edition. Mahwa New Jeresy London: Lawrence Erlbaum Associates, Inc.

Robbins, SP. and TA, Judge. 2008. Organizational Behavior. Terjemahan Buku 1 \& II oleh Diana Angelicia, Ria Cahyani, dan Abdul Rasyid, Salemba Empat, Jakarta.

Robbins, SP. and WL, Kliewer. 2000. Advances in theory and research on subjective well-being. In S.D. Brown \& R.W. Lent (Eds.), Handbook of counseling psychology (3rded.), NewYork: Wiley.

Rooks, L. 2010. The Relationship between Life Satisfaction and Substance Use in Adolescence. A thesis submitted in partial fulfillment of the requirements for the degree of Education Specialist Department of Psychological and Social Foundations College of Education University of South Florida, $1-129$

Samman, E. 2007. Psychological and Subjecyive Wellbeing: A Proposal For Internationally Comparable Indicators. A modified version of this paper was published in the December, issue of Oxford Development Studies, 35(4), 459-487.

Senter, A., RD. Morgan, CS. McDonald and M. Bewley. 2010. Correctional Psychologist Burnout, JobSatisfaction, and Life 
Satisfaction. Psychological Services, American Psychological Association. 7(3). 190-201.

Shimazu, A., AB, Bakker, E, Demeroiti and M.CW, Peeters. 2010. Work Family Conflict in Japan: and Home Demand Affect Psychological Distess. Industrial Health. 48. 766-774.

Slocum, WJ. and D, Hellriegel. 2007. Fundamental of Organizational Behavior. Thomoson South-Western.

Veenhoven, R. 1996. Developments In Satisfaction-Research,
(Sociallndicators Research, Kluwer Academic Publishers, Printed in the Netherlands, 37. 1-46.

Wexley, NK. and AG, Yukl. 2005. Organizational Behavior and Personnel Psychology. Terjemahan oleh Muh. Sobaruddin, Rineka Cipta, Jakarta.

Zhao, DM. and H, Yamaguchi. 2008. Relationship of Challenge and Hindrance Stress With Coping Style and Job Satisfaction in Chinese State-Owned Enterprise. Japanese Journal of International and Social Psychology, 8. 7-87. 